Article

\title{
Energy Benchmarking of Existing Office Stock in Spain: Trends and Drivers
}

\author{
Marta Gangolells *®D, Miquel Casals ${ }^{\circledR}$, Jaume Ferré-Bigorra $₫$, Núria Forcada, \\ Marcel Macarulla ${ }^{\oplus}$, Kàtia Gaspar and Blanca Tejedor
}

Universitat Politècnica de Catalunya, Group of Construction Research and Innovation (GRIC), C/Colom, 11, Ed. TR5, 08222 Terrassa (Barcelona), Spain; miquel.casals@upc.edu (M.C.); jaume.ferre.bigorra@upc.edu (J.F.-B.); nuria.forcada@upc.edu (N.F.); marcel.macarulla@upc.edu (M.M.); katia.gaspar@upc.edu (K.G.);

blanca.tejedor@upc.edu (B.T.)

* Correspondence: marta.gangolells@upc.edu; Tel.: +34-93-7398947; Fax: +34-93-7398101

Received: 7 October 2019; Accepted: 8 November 2019; Published: 12 November 2019

\begin{abstract}
Buildings play a central role in the clean energy transition, which is why it is vital to understand how energy is consumed in this sector. Energy performance certificate databases are considered a key source of information on the characteristics of built building stock. Despite a growing portfolio of studies based on information from such databases, little is known about energy consumption in offices. This paper explores the modelled energy performance of existing offices in Spain, using data from 13,701 energy performance certificates collected by the Catalan Institute of Energy (ICAEN) in 2013-2018. Offices were found to consume between 202.66 and $212.10 \mathrm{kWh} / \mathrm{m}^{2}$.year and were mostly ranked in classes $\mathrm{C}$ and $\mathrm{D}(\sim 64 \%)$. Offices with $\mathrm{E}, \mathrm{F}$ or G labels represent $\sim 28 \%$ of the sample while $\mathrm{A}$ and $\mathrm{B}$ energy ratings are very scarce $(\sim 8 \%)$. Key drivers of energy consumption variation were found to be the office type, construction period, climate zone, renewable energy use, energy certification procedure and motivation for obtaining an energy performance certificate. Ownership was not found to affect average calculated energy consumption. The results will help policy makers to plan future energy conservation strategies.
\end{abstract}

Keywords: offices; energy performance certificates; energy consumption; Spain

\section{Introduction}

In 2012, the European Union set a 20\% energy savings target by 2020, under the Energy Efficiency Directive [1]. Six years later, in December 2018, the revised Energy Efficiency Directive [2] entered into force and established an EU energy efficiency target of at least 32.5\% for 2030. In addition, Directive 2018/2001 [3] set a binding target of at least 32\% energy from renewable sources at European Union level by 2030. Buildings play a central role in the clean energy transition [4] as they account for nearly $40 \%$ of final energy consumption [5] and represent approximately $36 \%$ of all $\mathrm{CO}_{2}$ emissions in the European Union [6].

In Spain, data from the long-term strategy for energy renovation in the building sector [7] indicate that the energy consumption of current building stock stands at $31.3 \%$ of final national energy consumption. Most previous studies have focused on limiting the residential sector's energy demand, which is $18.5 \%$ of final consumption. In second place are non-residential buildings, which represent $12.5 \%$ of Spain's final energy consumption [7] and have an average carbon intensity of the final energy demand of 1.02 metric tons of $\mathrm{CO}_{2}$ eq/toe [8]. In 2016, 283,532 offices with a total floor area of $111,291,436 \mathrm{~m}^{2}$ [9] consumed $3118 \mathrm{ktoe}$, which is almost one third (29.34\%) of the energy consumed by buildings that house services [10]. This figure is partly due to the growth of the services sector in recent years, especially in administrative, financial and consulting activities. In addition, the evolution 
of working methods and comfort standards have led to an increase in the energy intensity of offices. Offices tend to include an increasing amount of energy-consuming equipment such as computers, data processing centers, printers, scanners and photocopiers. In addition, a higher level of comfort is required, which often leads to greater energy expenditure on air conditioning, ventilation and lighting. To reduce this energy expenditure, we must understand how energy is consumed in the office sector [11].

Energy performance certificates were introduced in response to the Energy Performance Buildings Directive [12,13]. They are designed to help achieve energy efficiency targets by informing stakeholders in the building sector about buildings' energy efficiency [14]. A high proportion of the building stock now has an energy performance certificate, as these certificates are mandatory for new buildings, public buildings and existing buildings or building units that are for sale or rent. Databases for registering energy performance certificates are not compulsory but are considered a key source of information on the characteristics of built building stock [15]. Such databases are used to produce statistics on regional or national building stocks [5]. Table 1 summarises previous research initiatives using energy performance certificate databases to describe the efficiency of a nation's building stock. Despite a growing portfolio of studies based on energy performance certificate databases, little is known about energy consumption in offices. An analysis by Dascalaki et al. [16], Fabbri et al. [17], Dascalaki et al. [18] and Gangolells et al. [19] covered all the energy performance certificates included in their corresponding national databases, but unfortunately non-residential buildings were not differentiated by use. Only Armitage et al. [20] and Hjortling et al. [21] analysed in depth the final energy consumption of the office sector in England and Wales and Sweden, respectively.

Table 1. Previous research initiatives using energy performance certificate databases to describe the building stock. Source: own elaboration.

\begin{tabular}{cccc}
\hline Research Paper & Number of EPCs & Domain & Country \\
\hline Armitage et al. [20] & 2600 & Offices & England and Wales \\
Broberg and Egüez [22] & 90,039 & Residential & Sweden \\
Buratti et al. [23] & 6500 & Residential & Italy \\
Curtis et al. [24] & 410,348 & Residential & Ireland \\
Dall'O' et al. [25] & 175,778 & Residential & Italy \\
Dascalaki et al. [16] & 250 & Residential and non-residential & Greece \\
Dascalaki et al. [18] & 355,000 & Residential and non-residential & Greece \\
Dineen et al. [26] & 304,814 & Residential & Ireland \\
Droutsa et al. [27] & 650,000 & Residential & Greece \\
Fabbri et al. [17] & 1081 & Residential and non-residential & Italy \\
Fabbri [28] & 362,884 & Residential & Italy \\
Gangolells et al. [19] & 129,635 & Residential and tertiary & Spain \\
Godoy-Shimizu et al. [29] & 12,000 & Schools & United Kingdom \\
Hjortling et al. [21] & 186,021 & Commercial & Sweden \\
Hong et al. [30] & 8732 & Schools & United Kingdom \\
Hong et al. [31] & 7731 & Schools & United Kingdom \\
Johansson et al. [32] & 138,444 & Residential & Sweden \\
Kragh and Wittchen [33] & 235,000 & Residential & Denmark \\
Las-Heras-Casas et al. [34] & 36,072 & Residential & Spain \\
López-González et al. [35] & 9416 & Residential & Spain \\
Magalhães and Leal [36] & 259,775 & Residential & Portugal \\
Majcen et al. [37] & 233,670 & Residential & The Netherlands \\
Mangold et al. [38] & 17,620 & Residential & Sweden \\
Mangold et al. [39] & 5697 & Residential & Sweden \\
Prieler et al. [40] & 2645 & Residential & Austria \\
Reis and Escórcio [41] & 519 & Residential & Portugal \\
\hline
\end{tabular}

It is now five years since Royal Decree 235/2013 [42] was introduced in Spain and the database has reached a critical number of certificates that realistically reflect existing office stock. Therefore, the main objective of this paper is to characterise the existing office stock in terms of construction techniques and building systems through the information gathered in the energy performance certificates and to report on its energy performance on an aggregated level. This paper also examines the effects that variables 
such as office type, construction period, climate zone, use of renewable energy, ownership, motivation for obtaining an energy performance certificate and the energy certification procedure may have on the modelled energy use in the office sector. This paper uses 13,701 energy performance certificates for offices, collected by the Catalan Institute of Energy (ICAEN) since the entry into force of Royal Decree 235/2013 [42] in June 2013 up until July 2018. Following the introduction, the second section summarises the main aspects of the energy certification process in Spain. The third section presents the method and describes the sample and the fourth section discusses the results. Finally, the last section outlines the conclusions and highlights implications and future research.

\section{Energy Performance Certification in Spain}

In Spain, energy performance certificates for new buildings came into effect in 2007 with Royal Decree 47/2007 [43], in response to the Energy Performance Building Directive [12]. Existing buildings were addressed six years later in Royal Decree 235/2013 [42]. Since then, energy performance certificates have been mandatory for new and existing buildings, building units that are rented for the first time to a new tenant or buildings in the process of being sold. Energy performance certificates are also mandatory for buildings or building units of over $250 \mathrm{~m}^{2}$ occupied by a public authority and visited frequently by the public. Certificates are valid for 10 years, but they can be voluntarily updated before they expire. After the expiry date, the energy performance certificate must be renovated in the case of public buildings of over $250 \mathrm{~m}^{2}$. For other buildings, it must be renovated in the case of a new rental or sale.

Energy performance calculation methodology is based on modelled data. Therefore, outcomes are theoretical values corresponding to standard operating conditions, calculated based on the buildings physical characteristics (i.e., thermal envelopes, building systems, etc.). In this way, the Spanish rating focuses on the energy performance of the building, without considering the effect that buildings' occupancy or users' behavior may have on it. According to the Spanish labelling scheme, a building or a building unit can be ranked in one of seven classes depending on the generation of carbon dioxide emissions ( $\mathrm{kg} \mathrm{CO}_{2} / \mathrm{m}^{2}$.year), ranging from A (lowest generation of emissions) to $\mathrm{G}$ (highest generation of emissions). Energy performance certificates for new buildings erected after 2007 cannot have $\mathrm{G}$ or $\mathrm{F}$ labels. Energy performance certificates also include detailed information about modelled non-renewable primary energy consumption $\left(\mathrm{kWh}_{\mathrm{p}} / \mathrm{m}^{2}\right.$.year) for heating, cooling, domestic hot water and lighting and the corresponding energy ratings (ranging from $A$ to $G$ ).

Energy performance certificates must be issued by engineers and architects. The registration process is initiated when the technician completes an online form with basic data and attaches the software file (mandatory) and the energy performance certificate report (voluntary). In Catalonia, the Catalan Institute of Energy (ICAEN) is responsible for controlling, inspecting and registering energy performance certificates. Relevant data can be freely accessed online [44] and visualised using a geographic information system (GIS) tool [45]. Alternatively, the database of energy certificates including general data can be downloaded for offline processing [46]. Technical data is also available on request.

\section{Materials and Methods}

For the purpose of this research, the Catalan Institute of Energy (ICAEN) provided a complete database with all the information extracted from the energy performance certificates collected in Catalonia (northeast Spain). The certificates that were analysed were issued from June 2013 to July 2018, according to Royal Decree 235/2013 [42]. Due to confidentiality issues, the dataset was anonymised so that the building owner or the technician who issued the energy performance certificate could not be identified.

Original database files were gathered and organised into a single complete table, in which duplicated and non-relevant features were eliminated. For each energy performance certificate, over 150 features including general administrative data (i.e., registration number, building type, address, 
climate zone and other data), information related to energy performance (label, certification procedure and detailed information on energy demand, energy consumption and emissions), main characteristics of the office including geometry (i.e., useful floor area), thermal envelope (both opaque closures and openings) and existing facilities (i.e., heating, cooling and domestic hot water) were analysed. The database, originally built in Oracle, was exported into IBM SPSS Statistics v25.0 [47] for analysis.

The database originally included 13,701 energy performance certificates for offices. Several consistency checks (Table 2) identified energy performance certificates containing errors. Along the lines of Dall'O' et al. [25], database variables and other derived variables (for example, the shape factor that was calculated by dividing the building thermal envelope by the building volume) were filtered to detect non-reasonable values (exceptionally large or small figures, equal to zero or empty fields). Limits were set according to physical limitations, current and former regulations and other factors (Table 2). Some textual values had to be standardised. Other data entry errors were also detected and if possible corrected or otherwise deleted. After discarding non-valid energy performance certificates, the original database was reduced to 13,076 energy performance certificates for offices. Therefore, the sample used in this research represents approximately $95.44 \%$ of all the energy performance certificates that have been issued in Catalonia for offices. According to the Spanish Government's General Directorate for Land Registry [48], Catalonia currently has 47,212 offices and therefore the sample (in other words, the number of entries in the energy performance certificate database) was deemed appropriate and representative.

Table 2. Variables and threshold values used to detect errors in the energy performance certificate database. Source: own elaboration.

\begin{tabular}{cc}
\hline Variable & Value Threshold \\
\hline Useful floor area $\left(\mathrm{S}_{\mathrm{u}}\right)$ & $\mathrm{S}_{\mathrm{u}} \geq 10 \mathrm{~m}^{2}$ \\
Headroom $(\mathrm{h})$ & $2.2 \mathrm{~m} \leq \mathrm{h} \leq 5.0 \mathrm{~m}$ \\
Shape factor $(\mathrm{SF})$ & $0.01 \mathrm{~m}^{2} / \mathrm{m}^{3} \leq \mathrm{SF} \leq 2.30 \mathrm{~m}^{2} / \mathrm{m}^{3}$ \\
Thermal enclosure area $\left(\mathrm{S}_{\mathrm{te}}\right)$ & $\mathrm{S}_{\mathrm{te}} \geq 5 \mathrm{~m}^{2}$ \\
Non-renewable primary energy consumption $\left(\mathrm{E}_{\mathrm{p}}\right)$ & $24.4 \mathrm{kWh} / \mathrm{m}^{2} \cdot$ year $\leq \mathrm{E}_{\mathrm{p}} \leq 1000.0 \mathrm{kWh} \mathrm{p} / \mathrm{m}^{2} \cdot$ year \\
\hline
\end{tabular}

\subsection{Office Type}

After the validation process, the database included 13,076 energy performance certificates for offices, which represents approximately 3 million $\mathrm{m}^{2}$ (Table 3$)$. The majority $(10,131$ certificates, $77.48 \%)$ correspond to offices in residential buildings. These offices are located at street level or on higher floors of residential buildings and tend to be small (between $40.60 \mathrm{~m}^{2}$ and $215.00 \mathrm{~m}^{2}$ ). Typical examples include doctors' offices, dental clinics, lawyers' offices, real estate agencies, agencies undertaking administrative work and small consultancy firms, among others. The remaining 2945 energy performance certificates $(22.52 \%)$ were for office blocks (large buildings containing public or commercial offices) and offices in industrial buildings (offices located inside or adjacent to a building that is used for industrial activities). In this case, offices typically range from $47.68 \mathrm{~m}^{2}$ to $941.74 \mathrm{~m}^{2}$. The percentages of floor area are much more balanced. Offices in residential buildings represent $51.74 \%$ of the total floor area of buildings with energy certificates, whereas office blocks and offices in industrial buildings represent $48.26 \%$.

Table 3. Number of energy performance certificates and corresponding floor area according to office type. Source: drawn up by the authors using data from the Catalan Institute of Energy (ICAEN) database, July 2018.

\begin{tabular}{ccccc}
\hline \multirow{2}{*}{ Office Type } & \multicolumn{2}{c}{ Number of Energy Performance Certificates } & \multicolumn{2}{c}{ Floor Area } \\
\cline { 2 - 5 } & {$[\mathbf{u}]$.} & {$[\%]$} & {$\left[\mathbf{m}^{2}\right]$} & {$[\%]$} \\
\hline Office blocks and offices in industrial buildings & 2945 & 22.52 & $1,595,844$ & 51.74 \\
Offices in residential buildings & 10,131 & 77.48 & $1,488,548$ & 48.26 \\
Total & 13,076 & - & $3,084,393$ & - \\
\hline
\end{tabular}




\subsection{Construction Period}

Offices built before 1981 have no thermal protection, as the first legislation regulating buildings' thermal conditions, NBE-CT 79 [49], was introduced in Spain in 1979. This prescriptive code was in force from 1981 to 2006 and set minimum thermal requirements for individual building envelopes by establishing maximum heat transmission coefficients, and a maximum overall heat transmission coefficient for the entire building [50]. Thermal requirements were overhauled in 2007, when the Spanish Technical Building Code was introduced [51]. Another major change came in 2014 with the revision of the Spanish Technical Building Code's Section HE-1 on Energy Demand Limitation [52]. As shown in Table 4, offices listed in the energy performance certificate database were mostly built prior to 1981 (56.45\%), which compares well with the national statistical average. Offices meeting NBE-CT 79 [49] requirements represent $37.06 \%$ of the total. Offices built under the first version of the Spanish Technical Building Code [51] account for 5.14\%, whereas offices designed following the requirements of the 2013 revision of the Technical Building Code [52] represent just 1.35\% of all entries in the analysed database (Table 4). In general, offices in residential buildings were found to be older than office blocks and offices in industrial buildings. Of all offices built in the latest period (2014-2018), $72.32 \%$ correspond to office blocks and offices in industrial buildings and only $27.68 \%$ are offices in residential buildings.

Table 4. Number of energy performance certificates according to office type and construction period.

Source: drawn up by the authors using data from the ICAEN database, July 2018.

\begin{tabular}{|c|c|c|c|c|c|c|c|c|c|c|}
\hline \multirow{3}{*}{ Office Type } & \multicolumn{10}{|c|}{ Construction Year } \\
\hline & \multicolumn{2}{|c|}{ Prior to 1981} & \multicolumn{2}{|c|}{ 1981-2006 Period } & \multicolumn{2}{|c|}{ 2007-2013 Period } & \multicolumn{2}{|c|}{ 2014-2018 Period } & \multicolumn{2}{|c|}{ Total } \\
\hline & [u.] & {$[\%]$} & [u.] & [\%] & [u.] & {$[\%]$} & [u.] & {$[\%]$} & [u.] & {$[\%]$} \\
\hline Office blocks and offices in industrial buildings & 1094 & 37.15 & 1485 & 50.42 & 238 & 8.08 & 128 & 4.35 & 2945 & 100 \\
\hline Offices in residential buildings & 6287 & 62.06 & 3361 & 33.18 & 434 & 4.28 & 49 & 0.48 & 10,131 & 100 \\
\hline Total & 7381 & 56.45 & 4846 & 37.06 & 672 & 5.14 & 177 & 1.35 & 13,076 & 100 \\
\hline
\end{tabular}

\subsection{Climate Zone}

The latest modification of the Spanish Technical Building Code [52] defines 15 climate zones based on winter climate severity (WCS) and summer climate severity (SCS) [19]. Winter climate severity is a good indicator of energy demand for heating and is identified by a letter: A for locations with the warmest winter and $\mathrm{E}$ for locations with the coldest winter. Summer climate severity is an indicator of energy demand for cooling and is represented by a number: 1 for locations with the mildest summer and 4 for locations with the hottest summer.

In general, Barcelona and Girona provinces are in the $\mathrm{C} 2$ climate zone, whereas Tarragona is in the B3 climate zone and Lleida in the D3 climate zone (Figure 1). As shown in Table 5, most of the energy performance certificates included in the sample are in the $\mathrm{C} 2$ climate zone $(76.36 \%)$. Offices erected in the B3 climate zone represent $2.07 \%$ of the database whereas offices in the D3 climate zone account for $2.65 \%$. All locations in a province are considered to have the same climate zone as their capital, but a correction is devised for locations that differ by over $200 \mathrm{~m}$ of altitude from the corresponding capital. Therefore, in accordance with the population distribution, a high proportion of energy performance certificates in the database are from other climate zones such as D2 $(12.30 \%), \mathrm{C} 3(4.08 \%), \mathrm{D} 1(1.77 \%)$ and $\mathrm{E} 1(0.78 \%)$. 


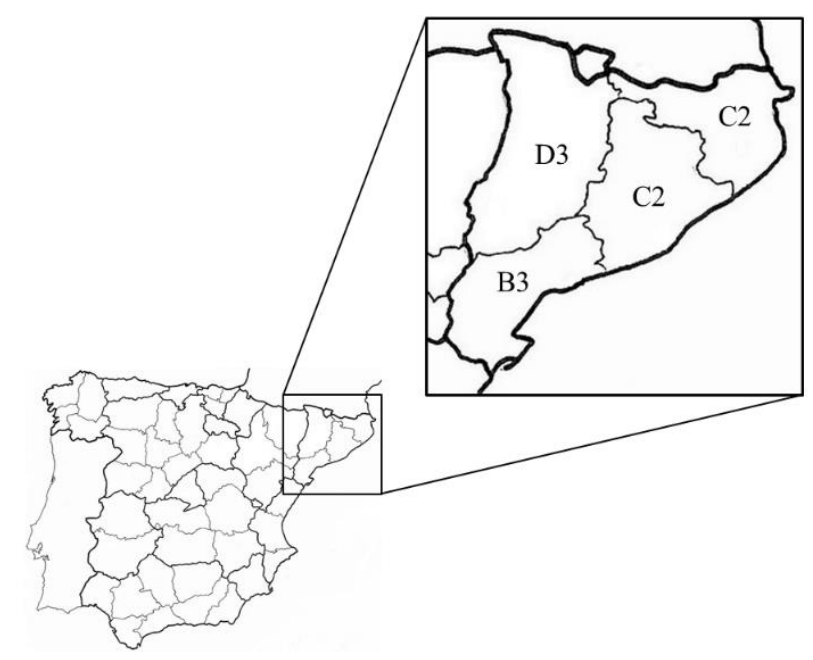

Figure 1. Climate zoning based on winter climate severity and summer climate severity according to the Spanish Technical Building Code [52]. Source: drawn up by the authors.

Table 5. Number of energy performance certificates according to office type and climate zone. Source: drawn up by the authors using data from the ICAEN database, July 2018.

\begin{tabular}{|c|c|c|c|c|c|c|c|c|c|c|c|c|c|c|c|c|}
\hline \multirow{4}{*}{ Office Type } & \multicolumn{16}{|c|}{ Climate Zone } \\
\hline & \multicolumn{6}{|c|}{ Province Capitals Zones } & \multicolumn{8}{|c|}{ Other Zones } & \multirow{2}{*}{\multicolumn{2}{|c|}{ Total }} \\
\hline & \multicolumn{2}{|c|}{$\mathrm{C} 2$} & \multicolumn{2}{|c|}{ B3 } & \multicolumn{2}{|c|}{ D3 } & \multicolumn{2}{|c|}{ D2 } & \multicolumn{2}{|c|}{$\mathrm{C} 3$} & \multicolumn{2}{|c|}{ D1 } & \multicolumn{2}{|c|}{ E1 } & & \\
\hline & [u.] & {$[\%]$} & [u.] & {$[\%]$} & [u.] & {$[\%]$} & [u.] & {$[\%]$} & [u.] & {$[\%]$} & [u.] & {$[\%]$} & [u.] & {$[\%]$} & [u.] & [\%] \\
\hline Office blocks and offices in industrial buildings & 1874 & 63.63 & 75 & 2.55 & 118 & 4.01 & 562 & 19.08 & 184 & 6.25 & 86 & 2.92 & 46 & 1.56 & 2945 & 100 \\
\hline Offices in residential buildings & 8111 & 80.06 & 196 & 1.93 & 228 & 2.25 & 1046 & 10.32 & 349 & 3.44 & 145 & 1.43 & 56 & 0.55 & 10,131 & 100 \\
\hline Total & 9985 & 76.36 & 271 & 2.07 & 346 & 2.65 & 1608 & 12.30 & 533 & 4.08 & 231 & 1.77 & 102 & 0.78 & 13,076 & 100 \\
\hline
\end{tabular}




\subsection{Renewable Energy Use}

Only $1.39 \%$ of offices met energy demand with solar, biomass or geothermal energy (Table 6). This percentage was slightly higher $(5.06 \%)$ for office blocks and offices in industrial buildings. In offices with renewable energy sources, the most widespread technology was solar thermal, followed by solar photovoltaics and biomass. Production of geothermal energy is still uncommon.

Table 6. Number of energy performance certificates by office type and renewable energy sources. Source: drawn up by the authors using data from the ICAEN database, July 2018.

\begin{tabular}{|c|c|c|c|c|c|c|c|c|c|c|}
\hline \multirow{3}{*}{ Office Type } & \multicolumn{8}{|c|}{ Renewable Energy Sources } & \multirow{2}{*}{\multicolumn{2}{|c|}{$\begin{array}{c}\text { Non-Renewable } \\
\text { Energy } \\
\text { Sources }\end{array}$}} \\
\hline & \multicolumn{2}{|c|}{$\begin{array}{c}\text { Solar } \\
\text { Thermal }\end{array}$} & \multicolumn{2}{|c|}{$\begin{array}{c}\text { Solar } \\
\text { Photovoltaics }\end{array}$} & \multicolumn{2}{|c|}{ Biomass } & \multicolumn{2}{|c|}{ Geothermal } & & \\
\hline & [u.] & {$[\%]^{1}$} & [u.] & {$[\%]^{1}$} & [u.] & {$[\%]^{1}$} & [u.] & {$[\%]^{1}$} & [u.] & {$[\%]^{1}$} \\
\hline Office blocks and offices in industrial buildings & 95 & 3.23 & 46 & 1.56 & 17 & 0.58 & 6 & 0.20 & 2796 & 94.94 \\
\hline Offices in residential buildings & 108 & 1.07 & 13 & 0.13 & 16 & 0.16 & 13 & 0.13 & 9990 & 98.61 \\
\hline Total & 203 & 1.55 & 59 & 0.45 & 33 & 0.25 & 19 & 0.15 & 12,786 & 97.78 \\
\hline
\end{tabular}

\subsection{Ownership and Motivation}

Regarding ownership (Table 7), the analysis revealed that most of the energy performance certificates in the database are for privately owned offices (96.50\%). This percentage is even higher for offices in residential buildings (98.83\%).

Table 7. Number of energy performance certificates according to office type and ownership. Source: drawn up by the authors using data from the ICAEN database, July 2018.

\begin{tabular}{ccccccc}
\hline \multirow{2}{*}{ Office Type } & \multicolumn{2}{c}{ Public } & \multicolumn{2}{c}{ Private } & \multicolumn{2}{c}{ Total } \\
\cline { 2 - 7 } & [u.] & {$[\%]$} & [u.] & {$[\%]$} & [u.] & {$[\%]$} \\
\hline Office blocks and offices in industrial buildings & 339 & 11.51 & 2606 & 88.49 & 2945 & 100 \\
Offices in residential buildings & 119 & 1.17 & 10,012 & 98.83 & 10,131 & 100 \\
Total & 458 & 3.50 & 12,618 & 96.50 & 13,076 & 100 \\
\hline
\end{tabular}

Most of the energy performance certificates were issued because of rent (62.33\%) and sale (28.65\%) transactions (Table 8). Energy performance certificates for public sector offices represent $2.91 \%$ of the database entries whereas voluntary certification accounts for $1.73 \%$. The number of certificates in the newly built offices category $(0.71 \%)$ was found to be negligible. The "others" category includes energy performance certificates needed for energy performance certificate renovation, grant applications and/or for building inspection reports. When the data were analysed by office type, a much higher proportion of energy performance certificates for public buildings was found in the office block subset $(9.78 \%)$ than in the offices in residential buildings subset $(0.91 \%)$.

\subsection{Energy Certification Procedure}

According to Royal Decree 235/2013 [42], an energy performance certificate can only be obtained using tools recognised by the Spanish Ministry for the Ecological Transition (Table 9).

As shown in Table 10, most of the energy performance certificates in the database were obtained using a simplified procedure (98.95\%), mainly CE3X (98.13\%). CE2 software was only recognised during the 2009-2014 period. The remaining 1.05\% of certificates were issued using a general procedure. Of them, only $0.67 \%$ were obtained using HULC, a software tool that has replaced the former Calener VyP and Calener GT since 2016, and 0.38\% were originally obtained using Calener VyP or Calener GT. The database did not include any energy performance certificates issued using CYPETHERM and SG Save, as these software tools were only recognised recently (2018) by the Spanish government. Most of the energy performance certificates obtained using a general procedure $(89.78 \%)$ correspond to office blocks and offices in industrial buildings. 
Table 8. Number of energy performance certificates by office type and the reason for issuing them. Source: drawn up by the authors using data from the ICAEN database, July 2018.

\begin{tabular}{|c|c|c|c|c|c|c|c|c|c|c|c|c|c|c|}
\hline \multirow{2}{*}{ Office Type } & \multicolumn{2}{|c|}{ Rental } & \multicolumn{2}{|c|}{ Sale } & \multicolumn{2}{|c|}{ Newly Built } & \multicolumn{2}{|c|}{ Public Offices } & \multicolumn{2}{|c|}{ Voluntary Certification } & \multicolumn{2}{|c|}{ Others } & \multicolumn{2}{|c|}{ Total } \\
\hline & [u.] & {$[\%]$} & [u.] & {$[\%]$} & [u.] & {$[\%]$} & [u.] & {$[\%]$} & [u.] & {$[\%]$} & [u.] & {$[\%]$} & [u.] & {$[\%]$} \\
\hline Office blocks and offices in industrial buildings & 1344 & 45.64 & 942 & 31.99 & 88 & 2.99 & 288 & 9.78 & 91 & 3.09 & 192 & 6.52 & 2945 & 100 \\
\hline Offices in residential buildings & 6806 & 67.18 & 2804 & 27.68 & 5 & 0.05 & 92 & 0.91 & 135 & 1.33 & 289 & 2.85 & 10,131 & 100 \\
\hline Total & 8150 & 62.33 & 3746 & 28.65 & 93 & 0.71 & 380 & 2.91 & 226 & 1.73 & 481 & 3.68 & 13,076 & 100 \\
\hline
\end{tabular}

Table 9. Recognised tools for energy performance certification of tertiary sector buildings in Spain in 2019. Source: adapted from ICAEN [53].

\begin{tabular}{|c|c|c|c|}
\hline & Building Type & Certification Procedure & Recognised Tools \\
\hline \multirow{3}{*}{ New buildings } & \multirow[t]{2}{*}{ Tertiary sector buildings } & General & $\begin{array}{l}\text { HULC } \\
\text { CYPETHERM } \\
\text { SG Save }\end{array}$ \\
\hline & & Simplified & CE3X \\
\hline & Large tertiary sector buildings & General & $\begin{array}{c}\text { HULC } \\
\text { CYPETHERM } \\
\text { SG Save }\end{array}$ \\
\hline \multirow{4}{*}{ Existing buildings } & \multirow{2}{*}{ Tertiary sector buildings } & General & $\begin{array}{l}\text { HULC } \\
\text { CYPETHERM } \\
\text { SG Save }\end{array}$ \\
\hline & & Simplified & $\begin{array}{c}\text { CE3X } \\
\text { CE3 }\end{array}$ \\
\hline & \multirow[t]{2}{*}{ Large tertiary sector buildings } & General & $\begin{array}{c}\text { HULC } \\
\text { CYPETHERM } \\
\text { SG Save }\end{array}$ \\
\hline & & Simplified & CE3X \\
\hline
\end{tabular}

Table 10. Number of energy performance certificates by office type and energy performance certification procedure. Source: drawn up by the authors using data from the ICAEN database, July 2018.

\begin{tabular}{|c|c|c|c|c|c|c|c|c|c|c|c|c|c|c|c|c|c|c|}
\hline \multirow{4}{*}{ Office Type } & \multicolumn{18}{|c|}{ Energy Performance Certification Procedure } \\
\hline & \multicolumn{10}{|c|}{ General Procedures } & \multicolumn{6}{|c|}{ Simplified Procedures } & \multirow{2}{*}{\multicolumn{2}{|c|}{ Total }} \\
\hline & \multicolumn{2}{|c|}{ HULC } & \multicolumn{2}{|c|}{ Calener VyP } & \multicolumn{2}{|c|}{ Calener GT } & \multicolumn{2}{|c|}{ CYPE-THERM } & \multicolumn{2}{|c|}{ SG Save } & \multicolumn{2}{|c|}{ CE3X } & \multicolumn{2}{|c|}{ CE3 } & \multicolumn{2}{|c|}{ CE2 } & & \\
\hline & [u.] & {$[\%]$} & [u.] & {$[\%]$} & [u.] & {$[\%]$} & [u.] & {$[\%]$} & [u.] & [\%] & [u.] & [\%] & [u.] & [\%] & [u.] & [\%] & [u.] & {$[\%]$} \\
\hline Office blocks and offices in industrial buildings & 78 & 2.65 & 35 & 1.19 & 10 & 0.34 & 0 & 0.00 & 0 & 0.00 & 2803 & 95.18 & 19 & 0.65 & 0 & 0.00 & 2945 & 100 \\
\hline Offices in residential buildings & 9 & 0.09 & 4 & 0.04 & 1 & 0.01 & 0 & 0.00 & 0 & 0.00 & 10,028 & 98.98 & 89 & 0.88 & 0 & 0.00 & 10,131 & 100 \\
\hline Total & 87 & 0.67 & 39 & 0.30 & 11 & 0.08 & 0 & 0.00 & 0 & 0.00 & 12,831 & 98.13 & 108 & 0.83 & 0 & 0.00 & 13,076 & 100 \\
\hline
\end{tabular}




\section{Results}

The following subsections examine the impact that office type, construction period, climate zone, renewable energy use, ownership, motivation for obtaining an energy performance certificate and energy certification procedure may have on the modelled primary energy consumption of offices.

The database had to be further filtered to discard energy performance certificates containing errors in energy consumption-related variables. All energy performance certificates with domestic hot water consumption above $0.40 \mathrm{kWh}_{\mathrm{f}} / \mathrm{m}^{2}$.year (7488) and those with an undefined lighting system (7495) had to be discarded. Consequently, key drivers for energy consumption variation were investigated using 4529 energy performance certificates for offices: 1073 for office blocks and offices in industrial buildings and 3456 for offices in residential buildings.

\subsection{Analysis by Office Type}

Figures 2 and 3 illustrate the frequency histograms for the non-renewable primary energy index $\left[\mathrm{kWh} / \mathrm{m}^{2} \cdot\right.$ year] by office type, covering all climate zones and all construction periods. As reported in other similar studies $[19,21,54]$, predicted non-renewable primary energy consumption was found to be highly positively skewed, because energy consumption cannot be negative, small numbers are rare, and there is high variability in aspects such as office geometry, thermal envelopes, HVAC systems and climate zones that clearly affect energy consumption. Figure 4 characterises the energy performance of each office type using a box-and-whisker plot. The top and bottom ends of the box respectively indicate the upper and lower quartiles (Q3 and Q1), while the band inside represents the median (or second quartile). The upper whisker (vertical line) marks the highest value below the limit defined by 1.5 interquartile ranges (IQR) added to the upper quartile (Q3 + 1.5.IQR). The lower whisker is the lowest value above the limit defined by 1.5 IQR deducted from the lower quartile (Q1 - 1.5.IQR). The floating point in the plot denotes the mean. Figures 5 and 6 represent the number of energy performance certificates by office type and energy rating.

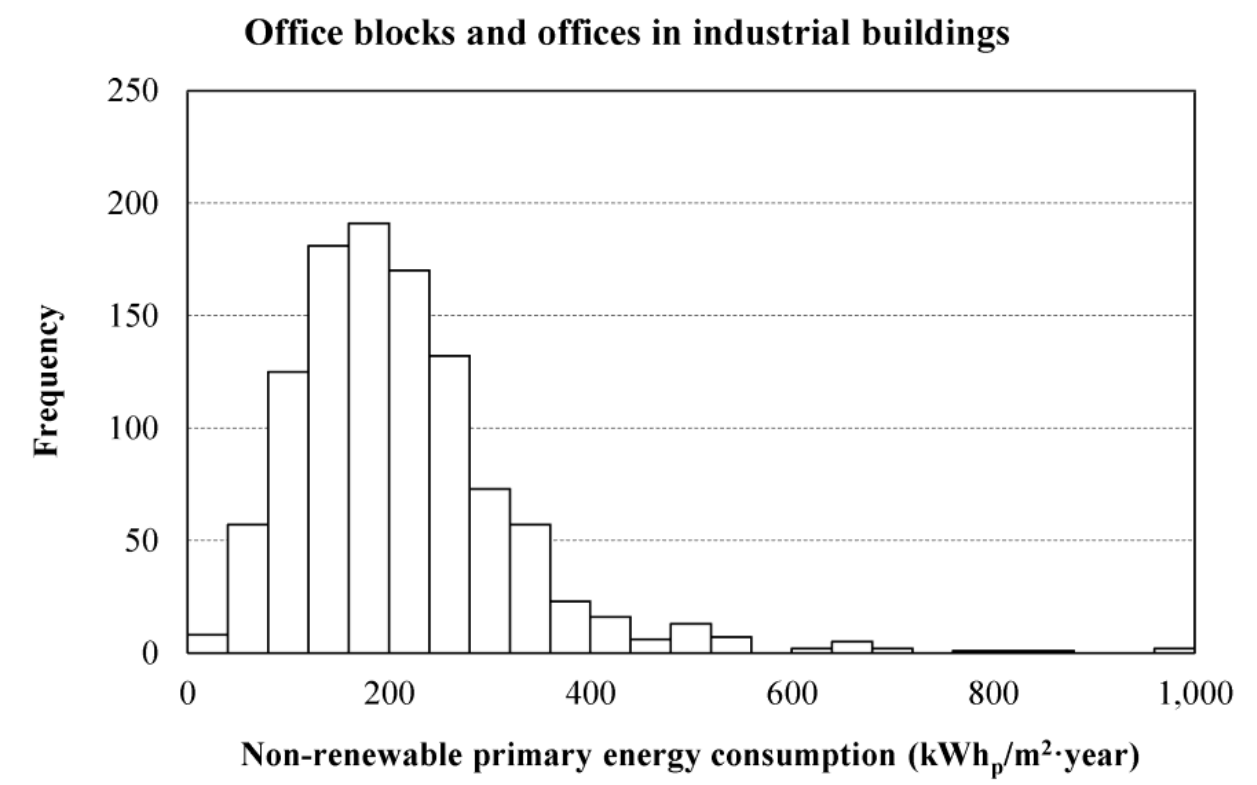

Figure 2. Frequency histogram of calculated non-renewable primary energy consumption $\left[\mathrm{kWh} / \mathrm{m} \mathrm{m}^{2} \cdot\right.$ year $]$ for office blocks and offices in industrial buildings. Source: drawn up by the authors using data from the ICAEN database, July 2018. 


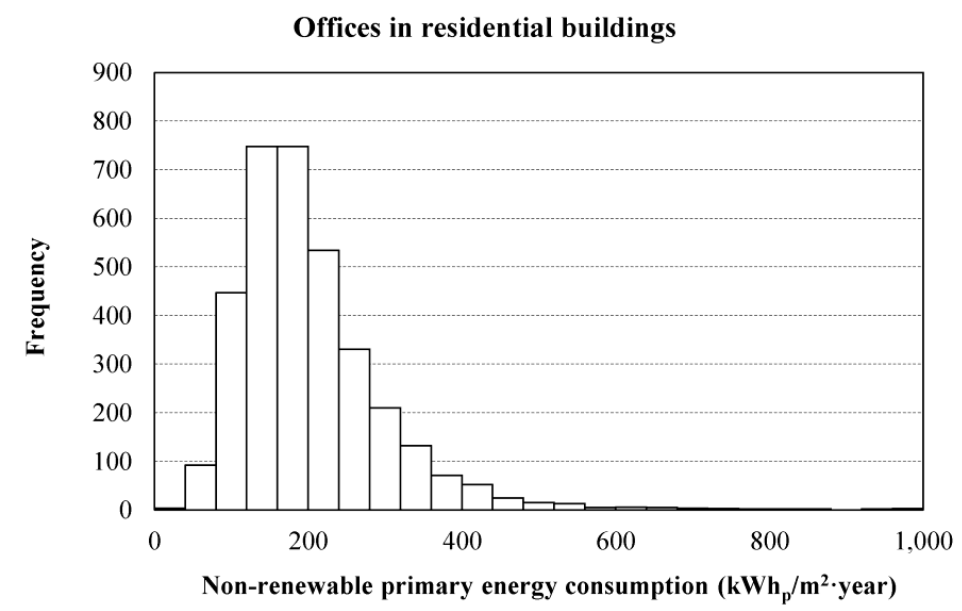

Figure 3. Frequency histogram of calculated non-renewable primary energy consumption $\left[\mathrm{kWh} / \mathrm{m}^{2} \cdot\right.$ year] for offices in residential buildings. Source: drawn up by the authors using data from the ICAEN database, July 2018.

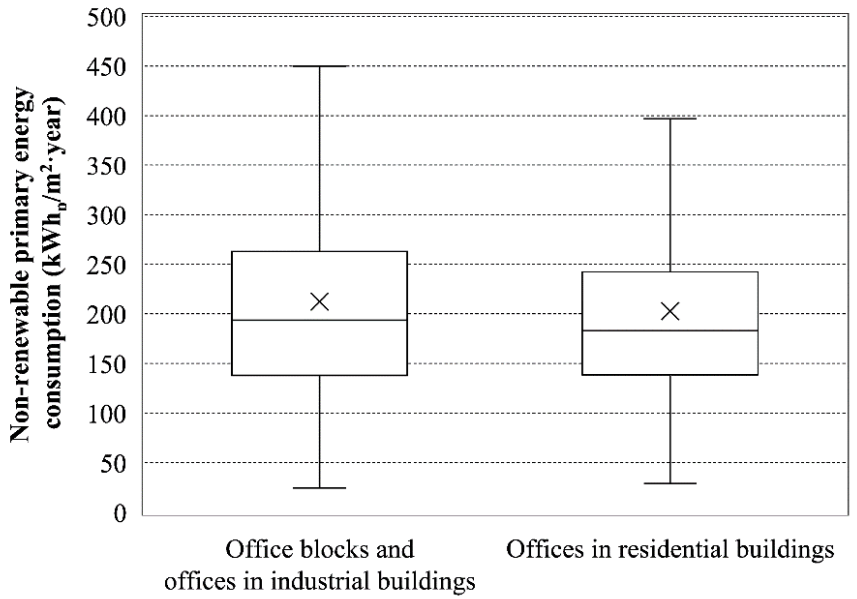

Figure 4. Box-and-whisker plot diagram for calculated non-renewable primary energy consumption $\left[\mathrm{kWh} / \mathrm{m}^{2}\right.$.year] by office type. Source: drawn up by the authors using data from the ICAEN database, July 2018.

Office blocks and offices in industrial buildings

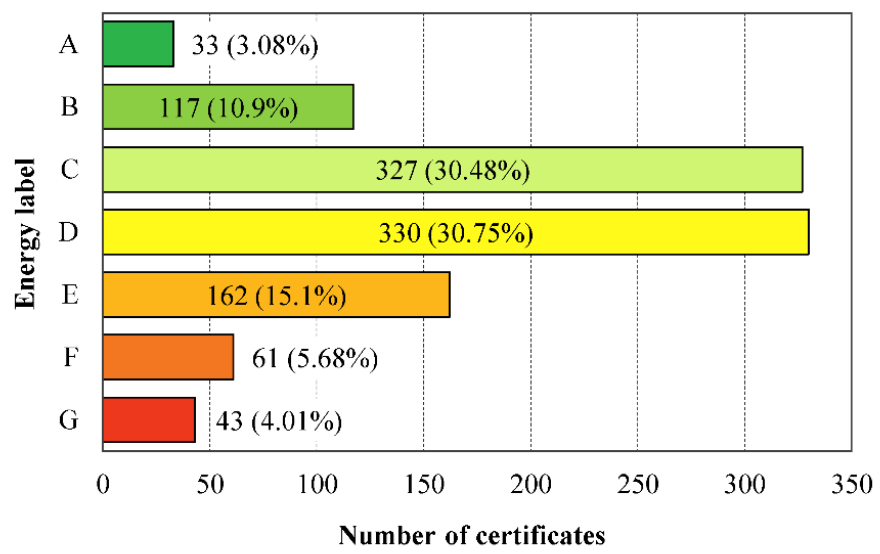

Figure 5. Number of energy performance certificates of office blocks and offices in industrial buildings according to the energy rating. Source: drawn up by the authors using data from the ICAEN database, July 2018. 
Offices in residential buildings

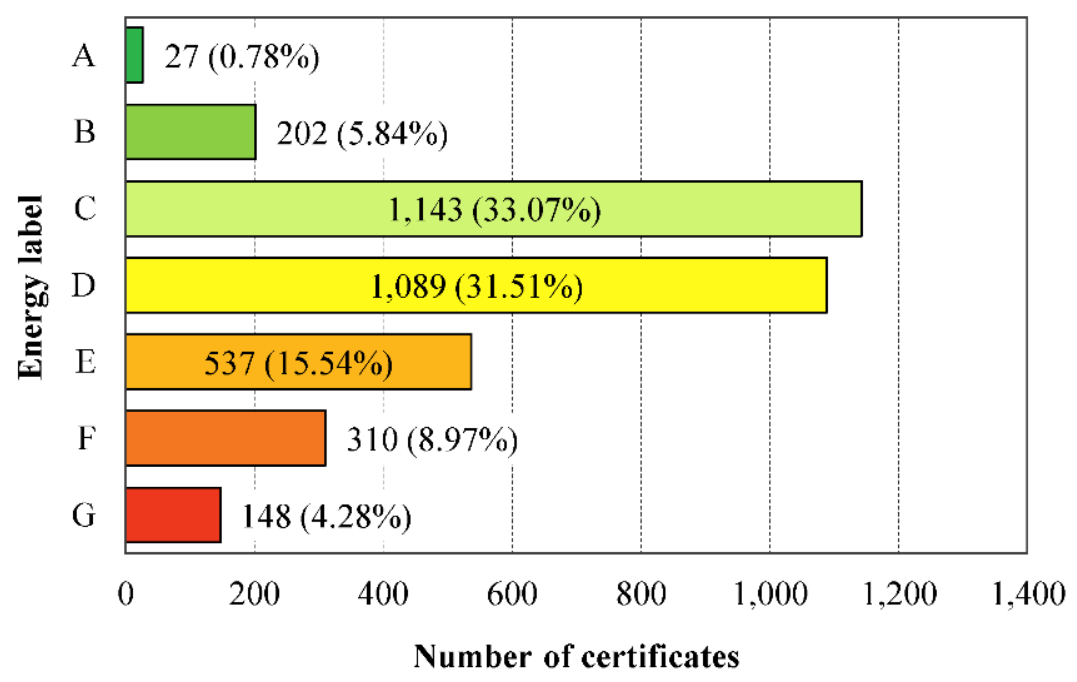

Figure 6. Number of energy performance certificates of offices in residential buildings according to energy rating. Source: drawn up by the authors using data from the ICAEN database, July 2018.

The mean calculated primary non-renewable energy use intensity of Spanish office blocks and offices in industrial buildings amounted to $212.10 \mathrm{kWh} / \mathrm{m}^{2}$.year (Figure 4). The median, sometimes used to define typical benchmarks [55], was $193.52 \mathrm{kWh} / \mathrm{m}^{2}$.year. According to the Spanish labelling scheme and as shown in Figure 5, 24.79\% of office blocks were ranked in class E or below and therefore have great potential for energy savings through retrofitting measures. Offices with $C$ and D labels represented $61.23 \%$ of the total. These offices can still provide energy savings through retrofitting solutions. Finally, just a few certificates (13.98\%) were in the two most efficient categories (A and B), in which there is little room for improvement.

Offices in residential buildings had mean calculated primary annual energy consumption of $202.66 \mathrm{kWh} / \mathrm{m}^{2}$.year in Spain (Figure 4). The median was $182.87 \mathrm{kWh} / \mathrm{m}^{2}$.year. A total of $28.79 \%$ of offices in residential buildings had E, F or G labels (Figure 6). According to the results, $64.58 \%$ of offices in residential buildings were $C$ and $D$ classes. A and B energy ratings were very scarce $(6.63 \%)$.

The lower simulated energy consumption of offices in residential buildings may be partially explained by a lower shape factor, that is, by lower exposure to external clime conditions and/or non-thermally conditioned spaces because they are generally surrounded by other buildings or building units. The shape factor (external surface-to-volume ratio) was $0.62 \mathrm{~m}^{2} / \mathrm{m}^{3}$ for office blocks and offices in industrial buildings and $0.44 \mathrm{~m}^{2} / \mathrm{m}^{3}$ for offices in residential buildings. Higher shape factors are related to a higher potential for heat transfer, solar gains, daylight, natural ventilation and infiltration [55]. Although the average energy and carbon intensity per square meter was around $4 \%$ lower for offices in residential buildings, the greater floor area of office blocks and offices in industrial buildings resulted in yearly energy consumption of around $227.84 \mathrm{GWh}_{\mathrm{p}}$ and over 41,000 metric tons of $\mathrm{CO}_{2}$ (Table 11). 
Table 11. Average and total calculated non-renewable primary energy consumption and emissions generation by office type. Source: drawn up by the authors using data from the ICAEN database, July 2018.

\begin{tabular}{|c|c|c|c|c|c|c|}
\hline \multirow{2}{*}{ Office Type } & \multirow{2}{*}{$\begin{array}{c}\text { Average Primary Energy Consumption } \\
{\left[\mathrm{kWh}_{\mathrm{p}} / \mathrm{m}^{2} \cdot \text { year }\right]} \\
\end{array}$} & \multirow{2}{*}{$\frac{\text { Average Emissions Generation }}{[\mathrm{kg} \mathrm{CO}}$} & \multicolumn{2}{|c|}{ Total Primary Energy Consumption } & \multicolumn{2}{|c|}{ Total Emissions Generation } \\
\hline & & & {$\left[G W h_{p} /\right.$ year] } & [\%] & [t $\mathrm{CO}_{2} /$ year] & {$[\%]$} \\
\hline Office blocks and offices in industrial buildings & 212.10 & 39.36 & 227.84 & 61.62 & $41,271.17$ & 60.56 \\
\hline Offices in residential buildings & 202.66 & 37.94 & 141.91 & 38.38 & $26,873.13$ & 39.44 \\
\hline Total & - & - & 369.75 & - & $68,144.30$ & - \\
\hline
\end{tabular}




\subsubsection{Energy Breakdown}

Although office blocks and offices in industrial buildings consume more energy per square meter, the end-use percentages predicted under the assumptions of the model were found to be quite similar (Figure 7). However, HVAC installed power was found to be 2.75 times higher in office blocks and offices in industrial buildings than offices in residential buildings.

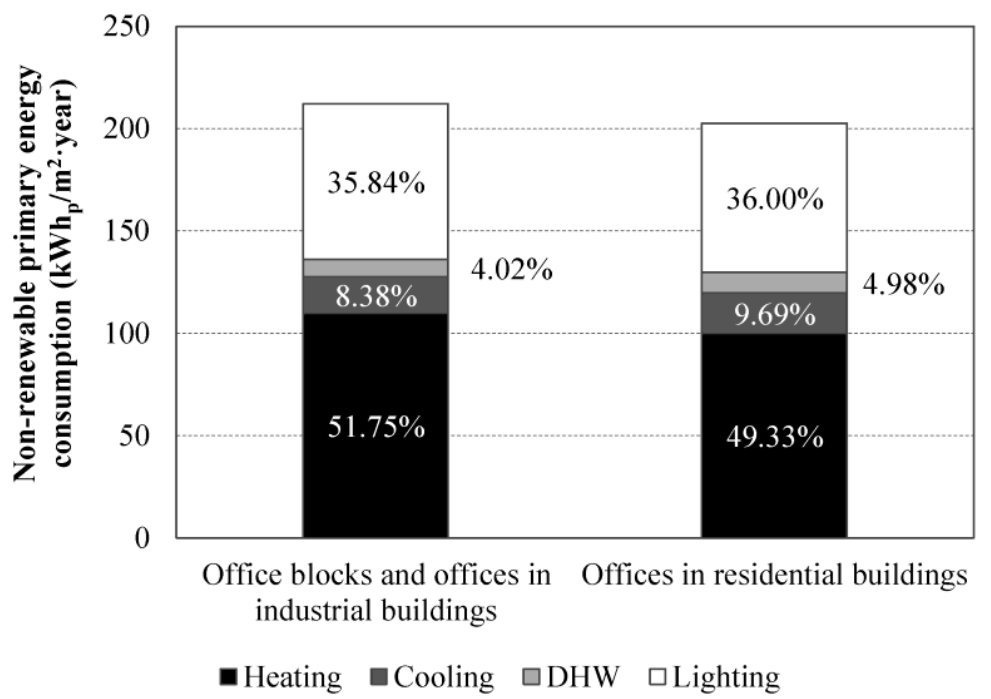

Figure 7. Breakdown of average calculated non-renewable primary energy consumption $\left[\mathrm{kWh} p / \mathrm{m}^{2} \cdot\right.$ year] according to the office type and end-uses. Source: drawn up by the authors using data from the ICAEN database, July 2018.

\subsubsection{Fuel Breakdown}

According to the data in the energy performance certificate database, most existing offices were heated. Only $2.33 \%$ of office blocks and offices in industrial buildings and $2.14 \%$ of offices in residential buildings had no heating system. A high proportion of offices also had a cooling system $(88.54 \%$ for office blocks and offices in industrial buildings and $88.92 \%$ for offices in residential buildings) to achieve a suitable level of comfort in summer (Table 12).

Table 12. Number of energy performance certificates according to available system and office type. Source: drawn up by the authors using data from the ICAEN database, July 2018.

\begin{tabular}{ccccccc}
\hline \multirow{2}{*}{ Fuel } & \multicolumn{2}{c}{ Heating } & \multicolumn{2}{c}{ Cooling } & \multicolumn{2}{c}{ Domestic Hot Water } \\
\cline { 2 - 7 } & {$[\mathbf{u . ]}$} & {$[\%]$} & {$[\mathbf{u}]$.} & {$[\%]$} & {$[\mathbf{u}]$.} & {$[\%]$} \\
\hline \multicolumn{7}{c}{ Office blocks and offices in industrial buildings } \\
\hline Existing system & 1048 & 97.67 & 950 & 88.54 & 595 & 55.45 \\
No system & 25 & 2.33 & 123 & 11.46 & 478 & 44.55 \\
Total & 1073 & 100 & 1073 & 100 & 1073 & 100 \\
\hline \multicolumn{7}{c}{ Offices in residential buildings } \\
\hline Existing system & 3382 & 97.86 & 3,073 & 88.92 & 1494 & 43.23 \\
No system & 74 & 2.14 & 383 & 11.08 & 1962 & 56.77 \\
Total & 3456 & 100 & 3456 & 100 & 3456 & 100 \\
\hline
\end{tabular}

As shown in Table 13, most offices used electricity for heating $(90.79 \%)$, followed by natural gas $(5.59 \%)$. Electricity was the most common energy source for cooling $(99.84 \%)$. Domestic hot water was heated by electricity in $89.24 \%$ of offices, while in $9.57 \%$ of cases it was heated by natural 
gas. Offices including renewable energy and/or combined systems including both conventional and renewable energy sources were very scarce for the three end-uses.

Table 13. Number of energy performance certificates according to fuel and office type. Source: drawn up by the authors using data from the ICAEN database, July 2018.

\begin{tabular}{|c|c|c|c|c|c|c|}
\hline \multirow{2}{*}{ Fuel } & \multicolumn{2}{|c|}{ Heating } & \multicolumn{2}{|c|}{ Cooling } & \multicolumn{2}{|c|}{ Domestic Hot Water } \\
\hline & [u.] & {$[\%]$} & [u.] & {$[\%]$} & [u.] & {$[\%]$} \\
\hline \multicolumn{7}{|c|}{ Office blocks and offices in industrial buildings } \\
\hline Electricity & 520 & 84.42 & 745 & 99.73 & 503 & 88.87 \\
\hline Natural gas & 51 & 8.28 & 1 & 0.13 & 50 & 8.83 \\
\hline Diesel oil & 9 & 1.46 & 0 & 0.00 & 7 & 1.24 \\
\hline Renewable energy/combined systems & 8 & 1.30 & 1 & 0.13 & 2 & 0.35 \\
\hline Others ${ }^{1}$ & 28 & 4.55 & 0 & 0.00 & 4 & 0.71 \\
\hline Total $^{2}$ & 616 & 100 & 747 & 100 & 566 & 100 \\
\hline \multicolumn{7}{|c|}{ Offices in residential buildings } \\
\hline Electricity & 1738 & 92.89 & 2308 & 99.87 & 1222 & 89.39 \\
\hline Natural gas & 88 & 4.70 & 1 & 0.04 & 135 & 9.88 \\
\hline Diesel oil & 21 & 1.12 & 1 & 0.04 & 5 & 0.37 \\
\hline Renewable energy/combined systems & 1 & 0.05 & 0 & 0.00 & 1 & 0.07 \\
\hline Others ${ }^{1}$ & 23 & 1.23 & 1 & 0.04 & 4 & 0.29 \\
\hline Total $^{2}$ & 1871 & 100 & 2311 & 100 & 1367 & 100 \\
\hline
\end{tabular}

Based on the models and their assumptions, the calculated energy consumption of offices was mostly covered by electricity and to a much lesser extent by natural gas for the three end-uses. Heating mostly relied on electricity $(89.57 \%)$ and natural gas $(6.30 \%)$. Office cooling was mostly powered by electricity $(99.89 \%)$. Energy consumption of domestic hot water was mainly covered with electricity $(95.65 \%)$, with a small percentage powered by natural gas $(3.96 \%)$. In all cases, the use of renewable energy sources was limited. No significant changes were detected by office type, except a slightly higher percentage of electricity use in the heating systems of offices in residential buildings.

In the analysis of fuel prevalence in relation to climate zone, biomass and diesel were found to be used most for heating in rural areas (such as the E1 climate zone) since natural gas distribution networks were less common in areas away from metropolitan cities. In terms of construction period, newer offices were most likely to include a heating and cooling system. Offices built after the introduction of the Spanish Technical Building Code mostly relied on electricity and never used diesel oil.

\subsection{Analysis by Construction Period}

The predicted energy performance of the offices was strongly influenced by construction period, in other words, by the building code (Figure 8 ). The average calculated energy consumption decrease between the oldest offices and the newest offices amounts to $52.71 \%$ for office blocks and offices in industrial buildings and $45.55 \%$ for offices in residential buildings. However, the first category in the graph of offices built prior to 1981 includes a high number of offices (2443) with varying construction quality levels [50]. Figure 8 clearly shows the impact of the Spanish Technical Building Code and its subsequent revision. 


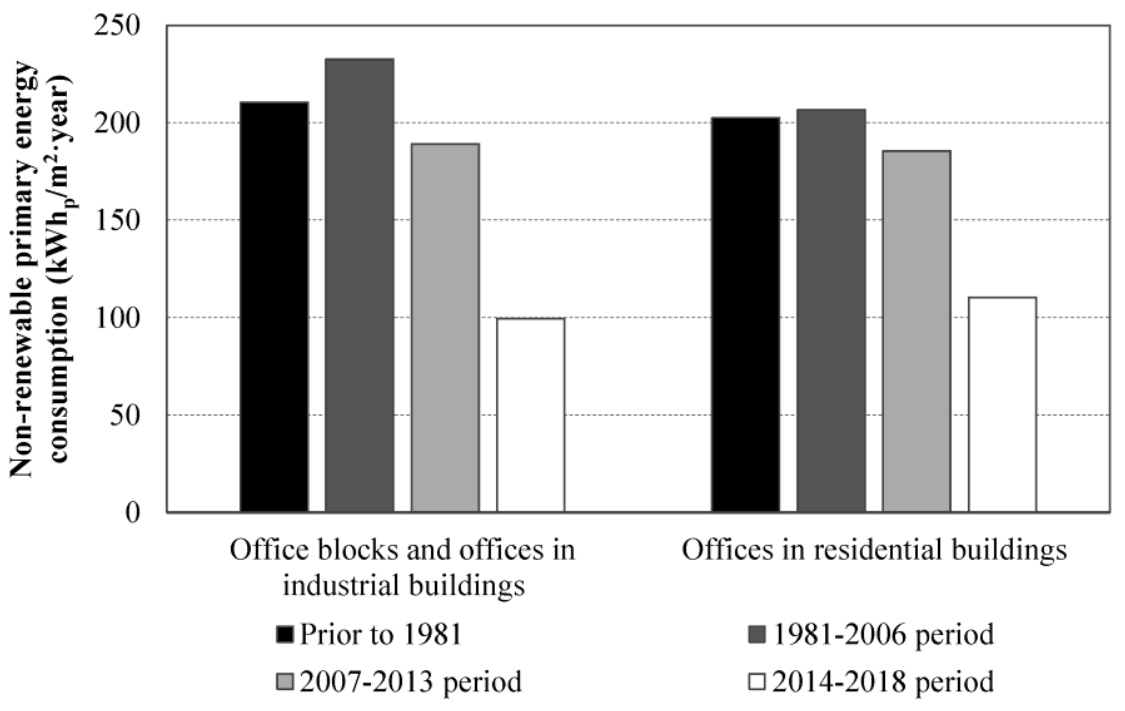

Figure 8. Average calculated non-renewable primary energy consumption $\left[\mathrm{kWh} / \mathrm{m}^{2} \cdot\right.$ year] by office type and construction period. Source: drawn up by the authors using data from the ICAEN database, July 2018.

Older buildings had the worst emission labels (Figure 9, Figure 10). A total of $4.46 \%$ of certificates for offices erected before 1980 were labelled G, but no new offices had this label. Of the modern offices, $26.53 \%$ were certified as class A and $57.14 \%$ were certified as class B. In contrast, $0.65 \%$ of pre- 1981 offices were certified as class A and $5.24 \%$ as B. Similar results have been reported in other southern European countries such as Greece [27], Portugal [36] and Spain [19].

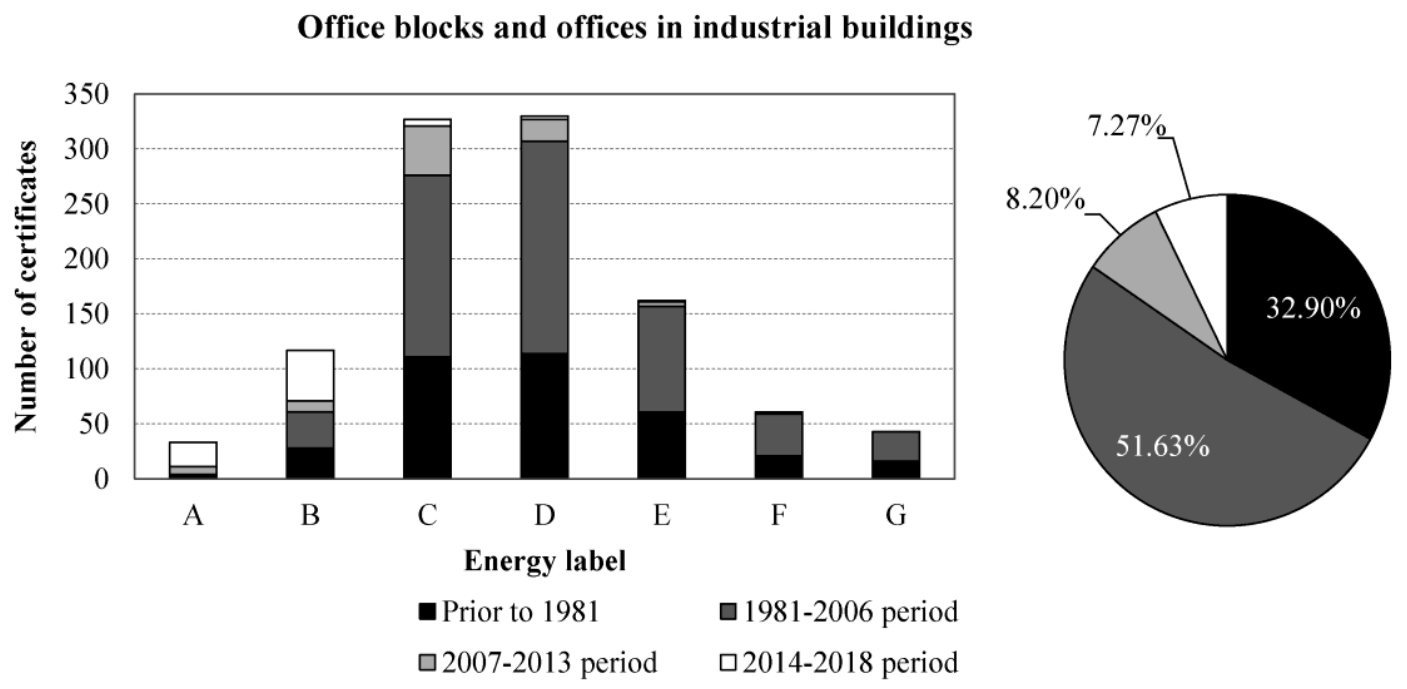

Figure 9. On the left, energy label of office blocks and offices in industrial buildings according to the construction period. On the right, share of energy performance certificates for office blocks and offices in industrial buildings according to construction period. Source: drawn up by the authors using data from the ICAEN database, July 2018. 


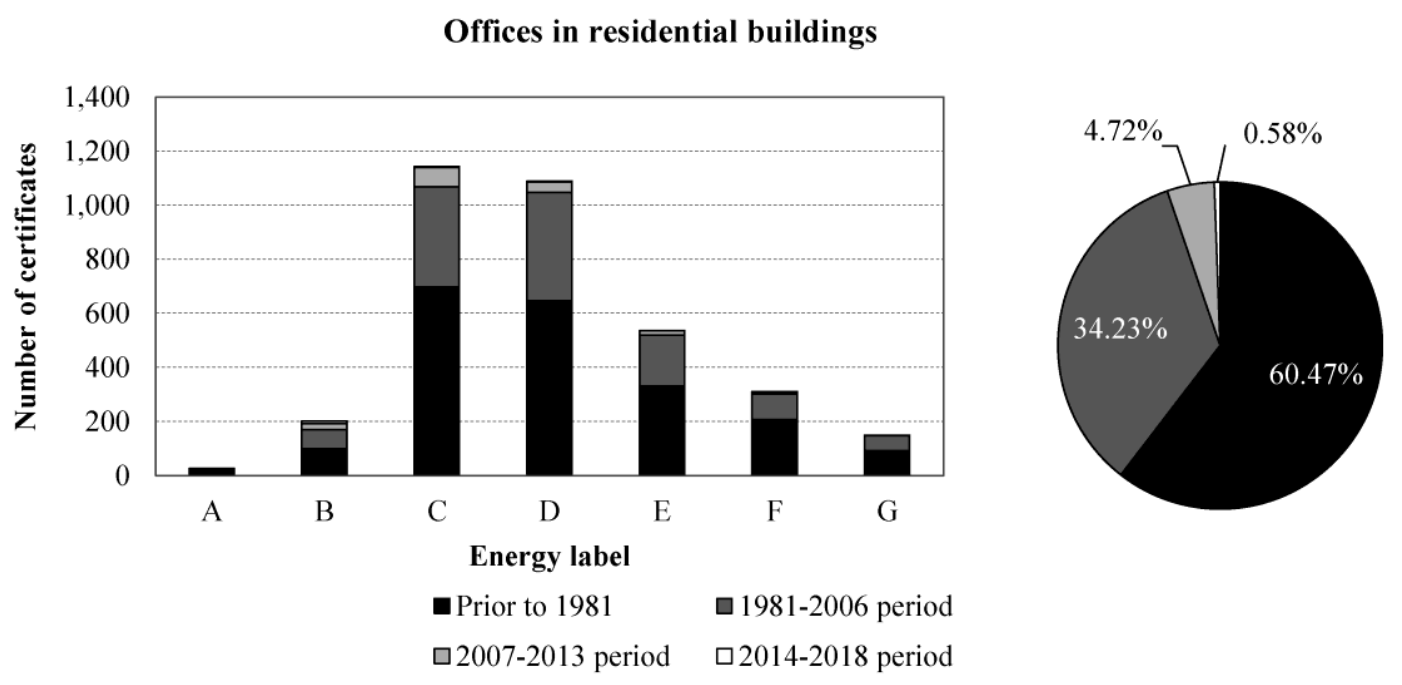

Figure 10. On the left, energy label of offices in residential buildings by construction period. On the right, share of energy performance certificates for offices in residential buildings according to construction period. Source: drawn up by the authors using data from the ICAEN database, July 2018.

The newest offices have clearly benefited from LED lighting (Figure 11). Offices built before 2014 are also expected to undergo progressive lighting renovation that will for sure result in a decreased energy consumption.

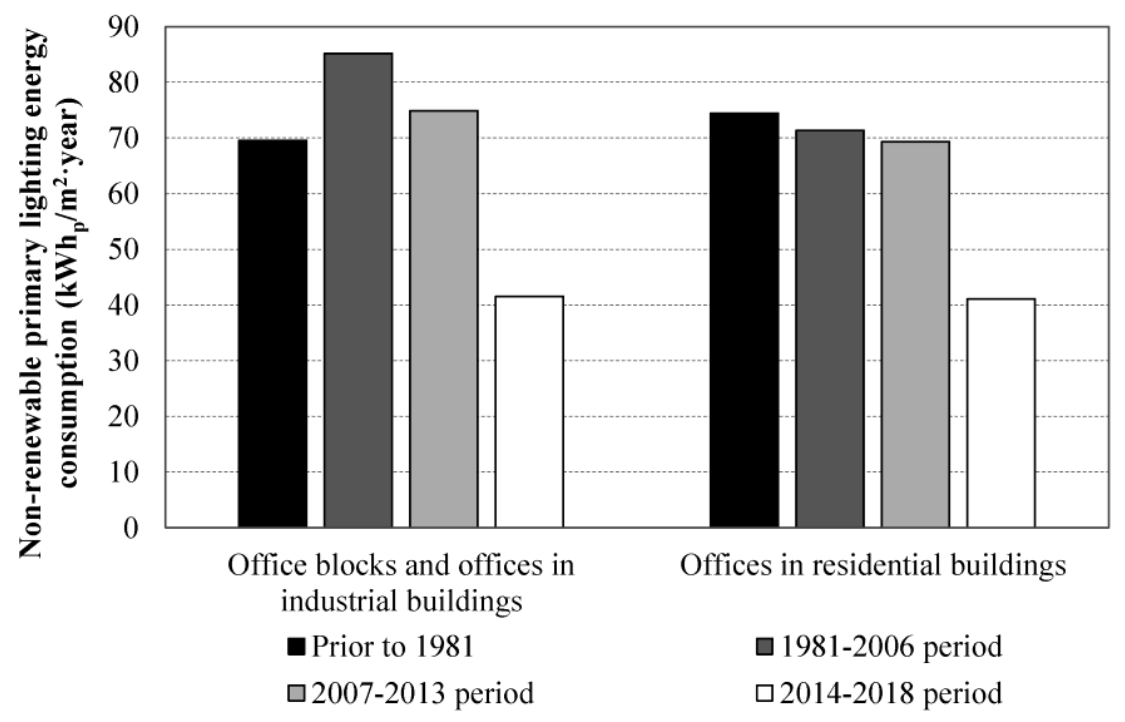

Figure 11. Average calculated non-renewable primary lighting energy consumption $\left[\mathrm{kWh} / \mathrm{m}^{2} \cdot \mathrm{year}\right]$ by office type and construction year. Source: drawn up by the authors using data from the ICAEN database, July 2018.

\subsection{Analysis by Climate Zone}

Figures 12 and 13 show the average calculated non-renewable primary heating and cooling energy consumption by office type and climate zone. Focusing on the energy used for heating purposes (Figure 12), the coldest climate zones in winter (D and E) had the highest energy consumption. The lowest heating consumption was found in the warmest climate zones in winter (B and C). The largest difference between the mean energy consumption of an office in the coldest zone and one located in the warmest zone was found to be $39.78 \%$. However, no significant trends could be observed 
in an analysis of the energy used for cooling and the hottest climate zones in summer (climate zones 2 and 3) (Figure 13). In general, the distribution of the energy label was not found to change significantly by climate zone.

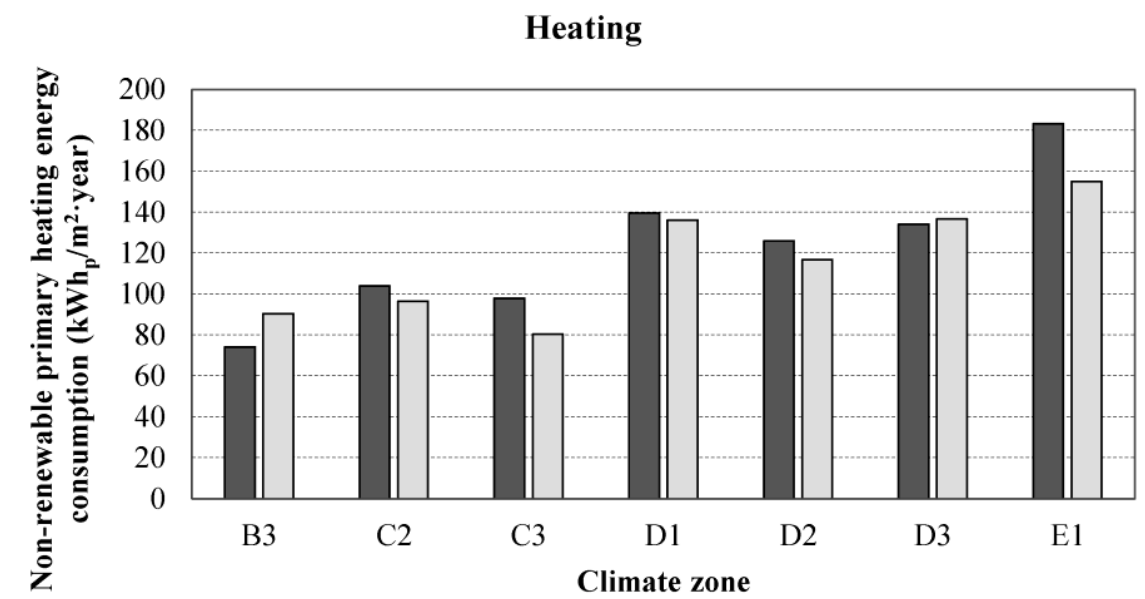

$\square$ Office blocks and offices in industrial buildings $\square$ Offices in residential buildings

Figure 12. Average calculated non-renewable primary heating energy consumption $\left[\mathrm{kWh} / \mathrm{m}^{2} \cdot\right.$ year] according to office type and climate zone. Source: drawn up by the authors using data from the ICAEN database, July 2018.

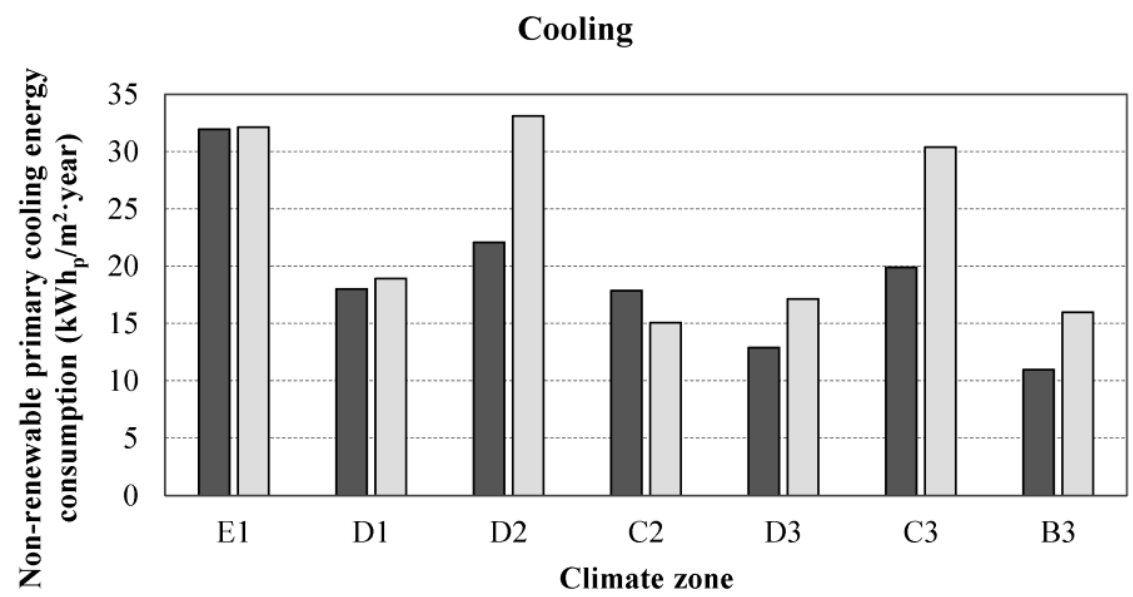

$\square$ Office blocks and offices in industrial buildings $\square$ Offices in residential buildings

Figure 13. Average calculated non-renewable primary cooling energy consumption $\left[\mathrm{kWh} / \mathrm{m}^{2} \cdot\right.$ year] according to office type and climate zone. Source: drawn up by the authors using data from the ICAEN database, July 2018.

Figure 14 provides a closer look at the impact of construction period and climate zone on modelled energy consumption in the most populated climate zones (C2, D2 and C3), which represent $92.58 \%$ of the analyzed offices. For example, in climate zone $\mathrm{C} 2$, the average calculated non-renewable primary energy consumption ranges from $232.68 \mathrm{kWh} / \mathrm{m}^{2}$.year (office blocks built between 1981 and 2006) to $94.39 \mathrm{kWh} / \mathrm{m}^{2}$.year (office blocks built between 2014 and 2018). New offices have significantly lower energy consumption for all office categories in all climate zones. Results for offices in residential buildings of the D2 climate zone built in the 2014-2018 period and offices of the C3 climate zone built in the 2007-2013 and 2014-2018 periods were not plotted because the sample size (0 to 6 certificates depending on the combination) was not representative enough. 


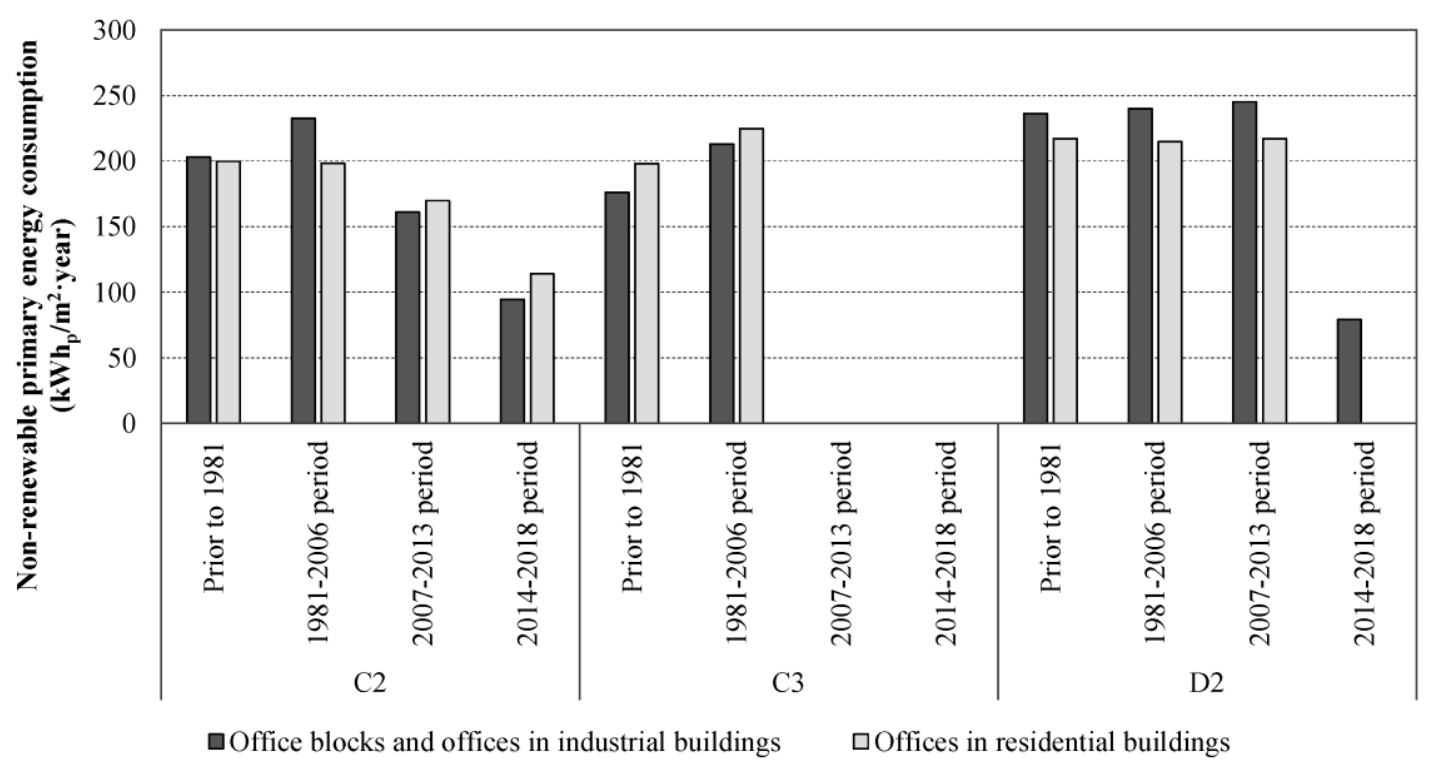

Figure 14. Average calculated non-renewable primary energy consumption $\left[\mathrm{kWh} / \mathrm{m}^{2}\right.$.year] by office type, construction period and climate zone. Source: drawn up by the authors using data from the ICAEN database, July 2018.

\subsection{Analysis by Energy Use}

The predicted renewable energy contribution under the assumptions of the model was found to range between $28.20 \%$ (offices in residential buildings) and $40.20 \%$ (office blocks and offices in industrial buildings) (Figure 15). As expected, modern offices had a higher penetration rate of renewable energy sources (Table 14). Data for offices in residential buildings built within the 2014-2018 period are not shown because of the small sample size (20 energy performance certificates).

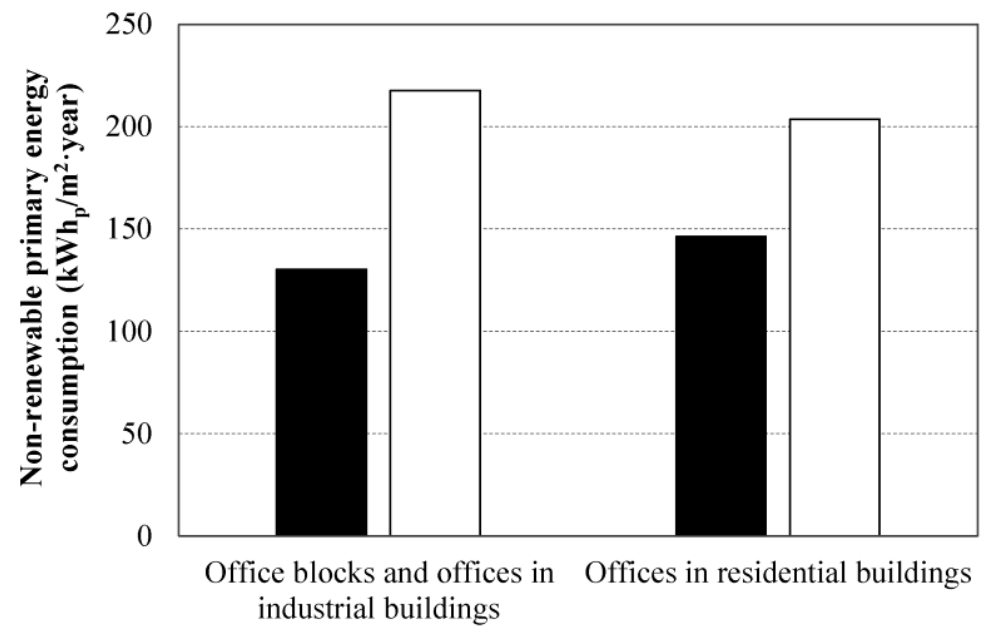

-With renewable energy sources $\square$ Without renewable energy sources

Figure 15. Average calculated non-renewable primary energy consumption $\left[\mathrm{kWh} / \mathrm{m}^{2}\right.$.year $]$ by office type and existence of renewable energy. Source: drawn up by the authors using data from the ICAEN database, July 2018. 
Table 14. Percentage of energy performance certificates including renewable energy by office type and construction period. Source: drawn up by the authors using data from the ICAEN database, July 2018.

\begin{tabular}{cccccc}
\hline \multirow{2}{*}{ Office Type } & \multicolumn{4}{c}{ Construction Year } \\
\cline { 2 - 5 } & Prior to 1981 & $\mathbf{1 9 8 1 - 2 0 0 6}$ Period & $\mathbf{2 0 0 7 - 2 0 1 3}$ Period & 2014-2018 Period & Total \\
\hline Office blocks and offices in industrial buildings & $1.70 \%$ & $3.61 \%$ & $15.91 \%$ & $35.90 \%$ & $100 \%$ \\
Offices in residential buildings & $0.57 \%$ & $0.68 \%$ & - & $100 \%$ \\
Total & $0.74 \%$ & $1.61 \%$ & $20.73 \%$ & $29.59 \%$ & $100 \%$ \\
\hline
\end{tabular}

\subsection{Analysis by Ownership and Motivation}

Ownership did not significantly impact the predicted non-renewable primary energy consumption of offices (Figure 16). Regarding the motivation for obtaining an energy performance certificate, the analysis revealed that energy performance certificates for newly built offices were found to have a much lower average energy consumption than those issued for other reasons, as expected (Figure 17). Slight differences were found between offices for sale and offices for rent (Figure 17).

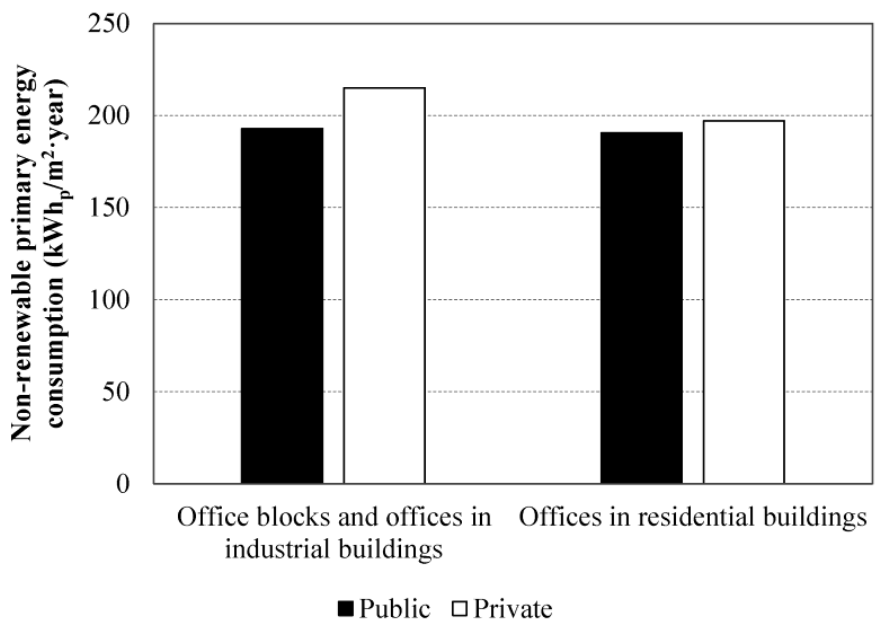

Figure 16. Average calculated non-renewable primary energy consumption $\left[\mathrm{kWh} / \mathrm{m}^{2} \cdot\right.$ year] according to office type and ownership. Source: drawn up by the authors using data from the ICAEN database, July 2018.

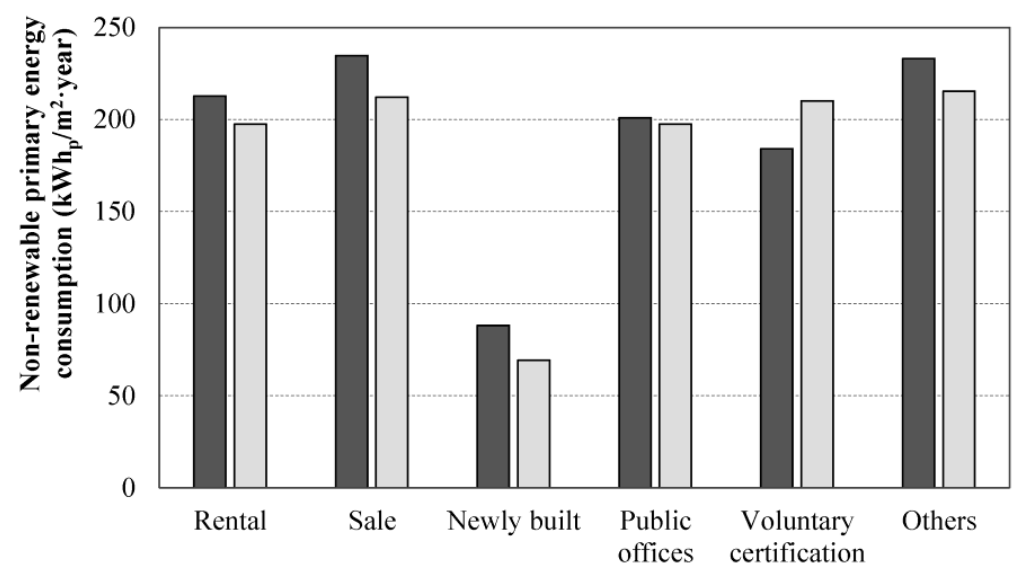

$\square$ Office blocks and offices in industrial buildings $\square$ Offices in residential buildings

Figure 17. Average calculated non-renewable primary energy consumption $\left[\mathrm{kWh} / \mathrm{m}^{2} \cdot\right.$ year $]$ according to office type and motivation. Source: drawn up by the authors using data from the ICAEN database, July 2018. 


\subsection{Analysis by Energy Certification Procedure}

Although the calculation methodology should not determine the result, energy performance certificates drawn up using the general procedure were found to consume less energy than those produced with the simplified procedure (Figure 18). Energy performance certificates created using simplified procedures tend to rely on default values, which may overestimate energy consumption. In addition, general procedures are mostly used when new buildings are certified with lower energy consumption. However, this analysis should be corroborated with a larger sample of energy performance certificates drawn up using general procedures to ensure that the limited data population of energy performance certificates obtained using a general procedure (101 versus 4428 certificates) does not bias the results.

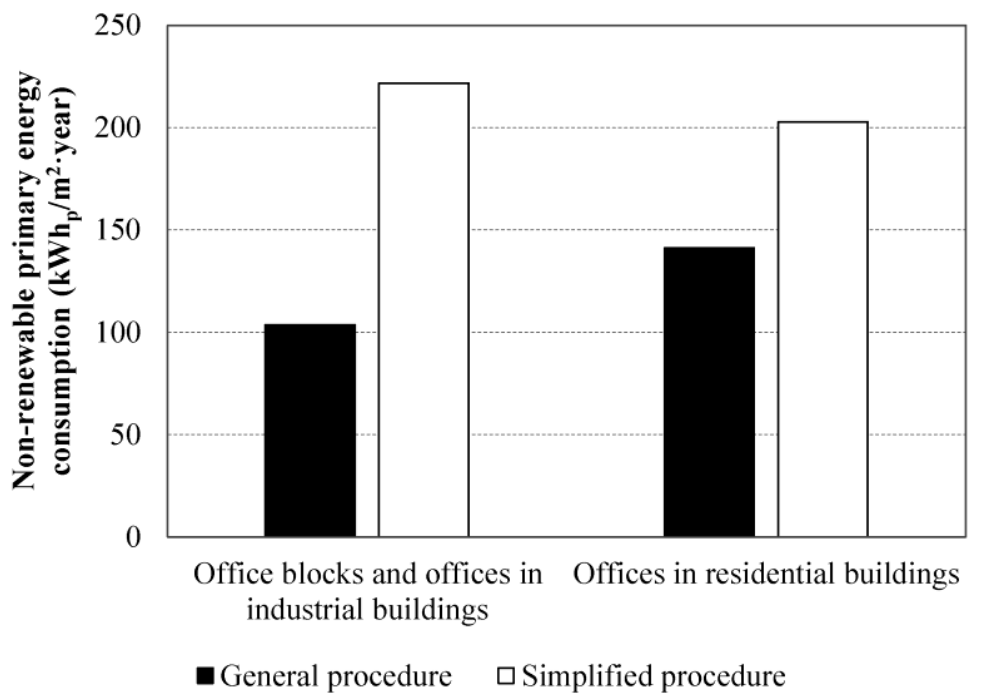

Figure 18. Average calculated non-renewable primary energy consumption $\left[\mathrm{kWh} p / \mathrm{m}^{2} \cdot\right.$ year] according to office type and certification procedure. Source: drawn up by the authors using data from the ICAEN database, July 2018.

\section{Discussion and Conclusions}

The paper examines the energy performance of existing Spanish office stock through a statistical analysis of the energy performance certificate database. Similar studies have been performed and continue to emerge throughout Europe revealing a wealth of information [27], but few approaches have analysed office stock in depth.

In this study, the existing office stock was characterised using 13,701 energy performance certificates for offices, issued in Catalonia since 2013. After discarding energy performance certificates containing errors in energy consumption-related variables, modelled energy use was investigated using 4529 energy performance certificates for offices. Although the predicted energy consumption can differ from the actual energy consumption [56], studies based on calculated energy performance effectively avoid the variability introduced by occupancy, users' behavior, equipment and appliances. The average calculated primary non-renewable energy consumption of Spanish office blocks and offices in industrial buildings was $212.10 \mathrm{kWh} / \mathrm{m}^{2}$.year whilst offices in residential buildings consumed slightly less (202.66 $\mathrm{kWh}_{\mathrm{p}} / \mathrm{m}^{2}$.year). According to results reported by Gangolells et al. [19] analysing the energy performance of both residential and tertiary sector buildings, it can be concluded that offices show a slightly better predicted energy performance than the average for tertiary sector buildings $\left(317.8 \mathrm{kWh} / \mathrm{m}^{2}\right.$.year). Offices consume slightly more energy than individual dwellings in multi-family blocks $\left(183.2 \mathrm{kWh} / \mathrm{m}^{2}\right.$.year) but less than single family houses $\left(248.0 \mathrm{kWh} / \mathrm{m}^{2}\right.$.year). Regardless of the office typology, the dominant energy classes were $\mathrm{C}$ and $\mathrm{D}(63.79 \%)$, followed closely by $\mathrm{E}, \mathrm{F}$ 
and G (27.84\%). Only $8.37 \%$ of offices were ranked in classes A or B. Under the assumptions of the model, most of the predicted energy was used for space heating $(49.93 \%)$, followed by lighting $(35.96 \%)$ and cooling $(9.37 \%)$. Domestic hot water represented $4.75 \%$ of total predicted energy consumption. Electricity was the dominant energy carrier with a projected contribution of about $95.92 \%$, varying from $93.09 \%$ in office blocks to $96.86 \%$ in offices in residential buildings. Natural gas was more commonly used in office blocks, with an average contribution of $3.49 \%$, and less in offices in residential buildings $(2.23 \%)$. Construction period and climatic conditions are key drivers of calculated energy consumption variation in offices. In general, old offices consume more energy and are mostly ranked in low energy classes. Although modelled energy consumption for space heating was found to correlate well with winter climatic severity, modelled energy consumption for office cooling does not to depend on summer climatic severity. A small percentage of offices (2.22\%) use renewable energy systems, but modern offices show a higher penetration rate than older ones. Whilst the analysis showed no impact of office ownership on average calculated primary energy consumption, the motivation for obtaining an energy performance certificate was significant. Energy performance certificates produced with the general procedure showed lower energy consumption than those performed with the simplified procedure.

One of the biggest concerns is related to the reliability of energy performance certificates. In this case, $66.94 \%$ of energy performance certificates contained non-reasonable information. The implementation of consistency checks has certainly reduced the possibility of errors in energy performance certificates and thus has increased the reliability of results. Results obtained in this research revealed variables with abnormal values, which indicated the aspects that should be carefully checked and subsequently improved within the most common energy performance certification tools. In this case, when the entire dataset was examined, domestic hot water energy consumption was found to be extremely high for offices. Technicians using a simplified energy certification procedure tend to overestimate domestic hot water demand because they often use the hot water volume coefficient set for dwellings instead of that set for offices. According to the Spanish Technical Building Code [52], the hot water volume coefficient is $28 \mathrm{~L}$ /day per occupant for dwellings and $2 \mathrm{~L} /$ day per occupant for offices. In addition, energy for lighting is often underestimated because technicians do not define the lighting system in the energy certification software. This is again a misunderstanding related to the energy certification procedure set for the residential domain. Energy performance certificates for dwellings do not cover energy for lighting, but this is not the case for energy performance certification of small and large tertiary sector buildings, which must always include lighting energy consumption.

Despite the limitations, the study contributes to energy benchmarking of the national office stock and therefore represents a good starting point for the long-term renovation strategies planned in the new Energy Performance Building Directive [6]. Energy performance certificate databases provide a unique opportunity for systematic, longitudinal, long-term monitoring of the building stock, particularly within the context of national roadmaps and corresponding measurable progress indicators.

Author Contributions: Conceptualization, M.G., M.C. and N.F.; Data curation, J.F.-B. and M.M.; Formal analysis, J.F.-B., M.M., K.G. and B.T.; Funding acquisition, M.G. and M.C.; Methodology, M.G. and N.F.; Project administration, M.G. and M.C.; Resources, M.G. and M.C.; Supervision, M.G. and M.C.; Validation, M.M.; Visualization, B.T.; Writing—original draft, M.G., J.F.-B. and K.G.; Writing—review \& editing, M.G., M.C. and N.F.

Funding: This research was funded by the Spanish Ministry of Economy, Industry and Competitiveness under R\&D project EOFF, reference no. BIA2016-75382-R (AEI/FEDER, UE).

Acknowledgments: The Catalan Institute of Energy (ICAEN) is gratefully acknowledged for allowing access to the energy performance certificate database.

Conflicts of Interest: The authors declare no conflict of interest. 


\section{References}

1. Directive 2012/27/EU of the European Parliament and of the Council of 25 October 2012 on energy efficiency, amending Directives 2009/125/EC and 2010/30/EU and repealing Directives 2004/8/EC and 2006/32/EC. Off. J. Eur. Union 2012, L 315, 1-56.

2. Directive (EU) 2018/2002 of the European Parliament and of the Council of 11 December 2018 amending Directive 2012/27/EU on energy efficiency. Off. J. Eur. Union 2018, L 328, 210-230.

3. Directive (EU) 2018/2001 of the European Parliament and of the Council of 11 December 2018 on the promotion of the use of energy from renewable sources. Off. J. Eur. Union 2018, L 328, 82-209.

4. International Energy Agency. 2018 Global Status Report: Towards a Zero-Emission, Efficient and Resilient Buildings and Construction Sector; IEA Publications: Paris, France, 2018; ISBN 978-92-807-3729-5.

5. Commission Recommendation (EU) 2019/786 of 8 May 2019 on building renovation. Off. J. Eur. Union 2019, L 127, 34-79.

6. Directive (EU) 2018/844 of the European Parliament and of the Council of 30 May 2018 amending Directive 2010/31/EU on the energy performance of buildings and Directive 2012/27/EU on energy efficiency. Off. J. Eur. Union 2018, L 156, 75-91.

7. 2017 Update of the Long-Term Strategy for Energy Renovation in the Building Sector in Spain (Actualización 2017 de la Estrategia a Largo Plazo para la Rehabilitación Energética en el Sector de la Edificación en España); Spanish Ministry of Public Works: Madrid, Spain, 2017.

8. Draft of the National Energy and Climate Plan for Spain 2021-2030 (Borrador del Plan Nacional Integrado de Energía y Clima 2021-2030); Spanish Ministry of Public Works: Madrid, Spain, 2019.

9. Long-Term Strategy for Energy Renovation in the Building Sector in Spain (Estrategia a Largo Plazo para la Rehabilitación Energética en el Sector de la Edificación en España); Spanish Ministry of Public Works: Madrid, Spain, 2014.

10. Yearly Report of Energy Consumption, Energy Breakdown for the Service Sector, Year 2016 (Informe Anual de Consumos Energéticos, Detalle de Consumes del Sector Servicios, Año 2016); Instituto para la Diversificación y Ahorro de la Energía: Madrid, Spain, 2016.

11. Wong, I.L.; Krüger, E.; Loper, A.C.M.; Mori, F.K. Classification and energy analysis of bank building stock: A case study in Curitiba, Brazil. J. Build. Eng. 2019, 23, 259-269. [CrossRef]

12. Directive 2002/91/EC of the European Parliament and of the Council of 16 December 2002 on the energy performance of buildings. Off. J. Eur. Union 2002, L 1, 65-71.

13. Directive 2010/31/EU of the European Parliament and of the Council of 19 May 2010 on the energy performance of buildings. Off. J. Eur. Union 2010, L 153, 13-35.

14. Pasichnyi, O.; Wallin, J.; Levihn, F.; Shahrokni, H.; Kordas, O. Energy performance certificates-New opportunities for data-enabled urban energy policy instruments? Energy Policy 2019, 127, 486-499. [CrossRef]

15. Buildings Performance Institute Europe. Future-Proof Buildings for all Europeans. A Guide to Implement the Energy Performance of Buildings Directive (2018/844); Buildings Performance Institute Europe: Brussels, Belgium, 2019.

16. Dascalaki, E.G.; Droutsa, K.; Gaglia, A.G.; Kontoyiannidis, S.; Balaras, C.A. Data collection and analysis of the building stock and its energy performance-An example for Hellenic buildings. Energy Build. 2010, 42, 1231-1237. [CrossRef]

17. Fabbri, K.; Zuppiroli, M.; Ambrogio, K. Heritage buildings and energy performance: Mapping with GIS tools. Energy Build. 2012, 48, 137-145. [CrossRef]

18. Dascalaki, E.G.; Kontoyiannidis, S.; Balaras, C.A.; Droutsa, K.G. Energy certification of Hellenic buildings: First findings. Energy Build. 2013, 65, 429-437. [CrossRef]

19. Gangolells, M.; Casals, M.; Forcada, N.; Macarulla, M.; Cuerva, E. Energy mapping of existing building stock in Spain. J. Clean. Prod. 2016, 112, 3895-3904. [CrossRef]

20. Armitage, P.; Godoy-Shimizu, D.; Steemers, K.; Chenvidyakarn, T. Using Display Energy Certificates to quantify public sector office energy consumption. Build. Res. Inf. 2015, 43, 691-709. [CrossRef]

21. Hjortling, C.; Björk, F.; Berg, M.; Klintberg, T. Energy mapping of existing building stock in Sweden-Analysis of data from Energy Performance Certificates. Energy Build. 2017, 153, 341-355. [CrossRef]

22. Broberg, T.; Egüez, A. Blame it on the owner-Ownership and energy performance of multi-dwelling buildings. Energy Econ. 2018, 72, 108-119. [CrossRef] 
23. Buratti, C.; Asdrubali, F.; Palladino, D.; Rotili, A. Energy Performance Database of Building Heritage in the Region of Umbria, Central Italy. Energies 2015, 8, 7261-7278. [CrossRef]

24. Curtis, J.; Devitt, N.; Whelan, A. Using census and administrative records to identify the location and occupancy type of energy inefficient residential properties. Sustain. Cities Soc. 2015, 18, 56-65. [CrossRef]

25. Dall'O', G.; Sarto, L.; Sanna, N.; Tonetti, V.; Ventura, M. On the use of an energy certification database to create indicators for energy planning purposes: Application in northern Italy. Energy Policy 2015, 85, 207-217. [CrossRef]

26. Dineen, D.; Rogan, F.; Gallachóir, B.Ó. Improved modelling of thermal energy savings potential in the existing residential stock using a newly available data source. Energy 2015, 90, 759-767. [CrossRef]

27. Droutsa, K.G.; Kontoyiannidis, S.; Dascalaki, E.G.; Balaras, C.A. Mapping the energy performance of hellenic residential buildings from EPC (energy performance certificate) data. Energy 2016, 98, 284-295. [CrossRef]

28. Fabbri, K. Building and fuel poverty, an index to measure fuel poverty: An Italian case study. Energy 2015, 89, 244-258. [CrossRef]

29. Godoy-Shimizu, D.; Armitage, P.; Steemers, K.; Chenvidyakarn, T. Using Display Energy Certificates to quantify schools' energy consumption. Build. Res. Inf. 2011, 39, 535-552. [CrossRef]

30. Hong, S.-M.; Paterson, G.; Burman, E.; Steadman, P.; Mumovic, D. A comparative study of benchmarking approaches for non-domestic buildings: Part 1-Top-down approach. Int. J. Sustain. Built Environ. 2013, 2, 119-130. [CrossRef]

31. Hong, S.-M.; Paterson, G.; Mumovic, D.; Steadman, P. Improved benchmarking comparability for energy consumption in schools. Build. Res. Inf. 2014, 42, 47-61. [CrossRef]

32. Johansson, T.; Olofsson, T.; Mangold, M. Development of an energy atlas for renovation of the multifamily building stock in Sweden. Appl. Energy 2017, 203, 723-736. [CrossRef]

33. Kragh, J.; Wittchen, K.B. Development of two Danish building typologies for residential buildings. Energy Build. 2014, 68, 79-86. [CrossRef]

34. Las-Heras-Casas, J.; López-Ochoa, L.M.; López-González, L.M.; Paredes-Sánchez, J.P. A tool for verifying energy performance certificates and improving the knowledge of the residential sector: A case study of the Autonomous Community of Aragón (Spain). Sustain. Cities Soc. 2018, 41, 62-72. [CrossRef]

35. López-González, L.M.; López-Ochoa, L.M.; Las-Heras-Casas, J.; García-Lozano, C. Energy performance certificates as tools for energy planning in the residential sector. The case of La Rioja (Spain). J. Clean. Prod. 2016, 137, 1280-1292. [CrossRef]

36. Magalhães, S.M.C.; Leal, V.M.S. Characterization of thermal performance and nominal heating gap of the residential building stock using the EPBD-derived databases: The case of Portugal mainland. Energy Build. 2014, 70, 167-179. [CrossRef]

37. Majcen, D.; Itard, L.; Visscher, H. Monitoring dwelling stock efficiency through energy performance register: Trends in Dutch social housing. In Proceedings of the Sustainable Building: Results. Are We Moving as Quickly as We Should? It's Up to Us, Barcelona, Spain, 28-30 October 2014; Volume 2, pp. 430-436.

38. Mangold, M.; Österbring, M.; Wallbaum, H. Handling data uncertainties when using Swedish energy performance certificate data to describe energy usage in the building stock. Energy Build. 2015, 102, 328-336. [CrossRef]

39. Mangold, M.; Österbring, M.; Overland, C.; Johansson, T.; Wallbaum, H. Building Ownership, Renovation Investments, and Energy Performance-A Study of Multi-Family Dwellings in Gothenburg. Sustainability 2018, 10, 1684. [CrossRef]

40. Prieler, M.; Leeb, M.; Reiter, T. Characteristics of a database for energy performance certificates. Energy Procedia 2017, 132, 1000-1005. [CrossRef]

41. Reis, J.A.; Escórcio, P. Energy certification in St. António (Funchal)—Statistical analysis. Energy Build. 2012, 49, 126-131. [CrossRef]

42. Royal Decree 235/2013 of 5 April, Approving the Basic Procedure for Certification of Energy Efficiency of Buildings (Real Decreto 235/2013, de 5 de Abril, Por el que se Aprueba el Procedimiento Básico para la Certificación de la Eficiencia Energética de los Edificios); Spanish Ministry of Presidency: Madrid, Spain, 2013; Volume 89.

43. Royal Decree 47/2007 of 19 January, Approving the Basic Procedure for Energy Certification of New Buildings (Real Decreto 47/2007, de 19 de Enero, Por el que se Aprueba el Procedimiento Básico para la Certificación de Eficiencia Energética de Edificios de Nueva Construcción); Spanish Ministry of Presidency: Madrid, Spain, 2007; Volume 27, pp. 4499-4507. 
44. ICAEN. Browser of Building Energy Performance Certificates (Buscador de Certificados de Eficiencia Energética de Edificios). Available online: https:/certificacioenergetica.gencat.cat/icaen-visor/AppJava/serv ices/certificats/show?language=es_ES (accessed on 6 June 2019).

45. ICAEN. Real-time Certificates Map (Mapa de Certificados en Tiempo Real). Available online: http://sig.gencat.cat/visors/hipermapa.html\#param=param\&color=vermell\&background=orto_ICC _grisos\&BBOX=410860,4567836,419125,4572271\&layers=ENERGIA_CERTIFICATS_EDIFICIS (accessed on 6 June 2019).

46. ICAEN. Register of Certified Buildings (Registro de Edificios Certificados). Available online: http://icaen.ge ncat.cat/es/1_icaen/dades_obertes/ (accessed on 6 June 2019).

47. IBM Corp. IBM SPSS Statistics for Windows; Version 25.0; IBM Corp: Armonk, NY, USA, 2017.

48. General Directorate for the Land Registry, Ministry of Finance, Spanish Government Cadastral Statistics. Available online: http://www.catastro.minhap.gob.es/esp/estadisticas.asp (accessed on 5 December 2018).

49. Royal Decree 2429/1979 of 6 July Approving Basic Building Regulations on Thermal Conditions in Buildings (Real Decreto 2429/1979, de 6 de Julio, Por el que se Aprueba la Norma Básica de Edificación NBE-CT-79, sobre Condiciones Térmicas en los Edificios); Presidency of the Spanish Government: Madrid, Spain, 1979; Volume 253, pp. 24524-24550.

50. Gangolells, M.; Casals, M. Resilience to increasing temperatures: Residential building stock adaptation through codes and standards. Build. Res. Inf. 2012, 40, 645-664. [CrossRef]

51. Royal Decree 314/2006 of 17 March Approving the Technical Building Code (Real Decreto 314/2006, de 17 de Marzo, Por el que se Aprueba el Código Técnico de la Edificación); Spanish Ministry of Housing: Madrid, Spain, 2006; Volume 74, pp. 11816-11831.

52. Order FOM/1635/2013 of 10 September Updating the Basic Document DB-HE Energy Savings of the Technical Building Code, Approved by Royal Decree 314/2006 of 17 March (Orden FOM/1635/2013, de 10 de Septiembre, Por la que se Actualiza el Documento Básico DB-HE Ahorro de Energía del Código Técnico de la Edificación, Aprobado por Real Decreto 314/2006, de 17 de Marzo); Spanish Ministry of Public Works: Madrid, Spain, 2013; Volume 219.

53. ICAEN. Tools of energy efficiency qualification (Herramientas de calificación de la eficiencia energética). Available online: http://icaen.gencat.cat/ca/energia/usos_energia/edificis/certificacio/informacio_professional (accessed on 6 June 2019).

54. Xiao, H.; Wei, Q.; Jiang, Y. The reality and statistical distribution of energy consumption in office buildings in China. Energy Build. 2012, 50, 259-265. [CrossRef]

55. Godoy-Shimizu, D.; Steadman, P.; Hamilton, I.; Donn, M.; Evans, S.; Moreno, G.; Shayesteh, H. Energy use and height in office buildings. Build. Res. Inf. 2018, 46, 845-863. [CrossRef]

56. Better Buildings Partnership. Helping Businesses to Improve the Way They Use Energy: Call for Evidence; Better Buildings Partnership: London, UK, 2018. 